\title{
The McAllister Park Roadway System Extension Project, San Antonio, Texas
}

Steve A. Tomka

Raba Kistner

Rick C. Robinson

Follow this and additional works at: https://scholarworks.sfasu.edu/ita

Part of the American Material Culture Commons, Archaeological Anthropology Commons, Environmental Studies Commons, Other American Studies Commons, Other Arts and Humanities Commons, Other History of Art, Architecture, and Archaeology Commons, and the United States History Commons

Tell us how this article helped you.

This Article is brought to you for free and open access by the Center for Regional Heritage Research at SFA ScholarWorks. It has been accepted for inclusion in Index of Texas Archaeology: Open Access Gray Literature from the Lone Star State by an authorized editor of SFA ScholarWorks. For more information, please contact cdsscholarworks@sfasu.edu. 


\section{The McAllister Park Roadway System Extension Project, San Antonio, Texas Creative Commons License \\ (c) $)(1)$ (9)}

This work is licensed under a Creative Commons Attribution-NonCommercial 4.0 International License 


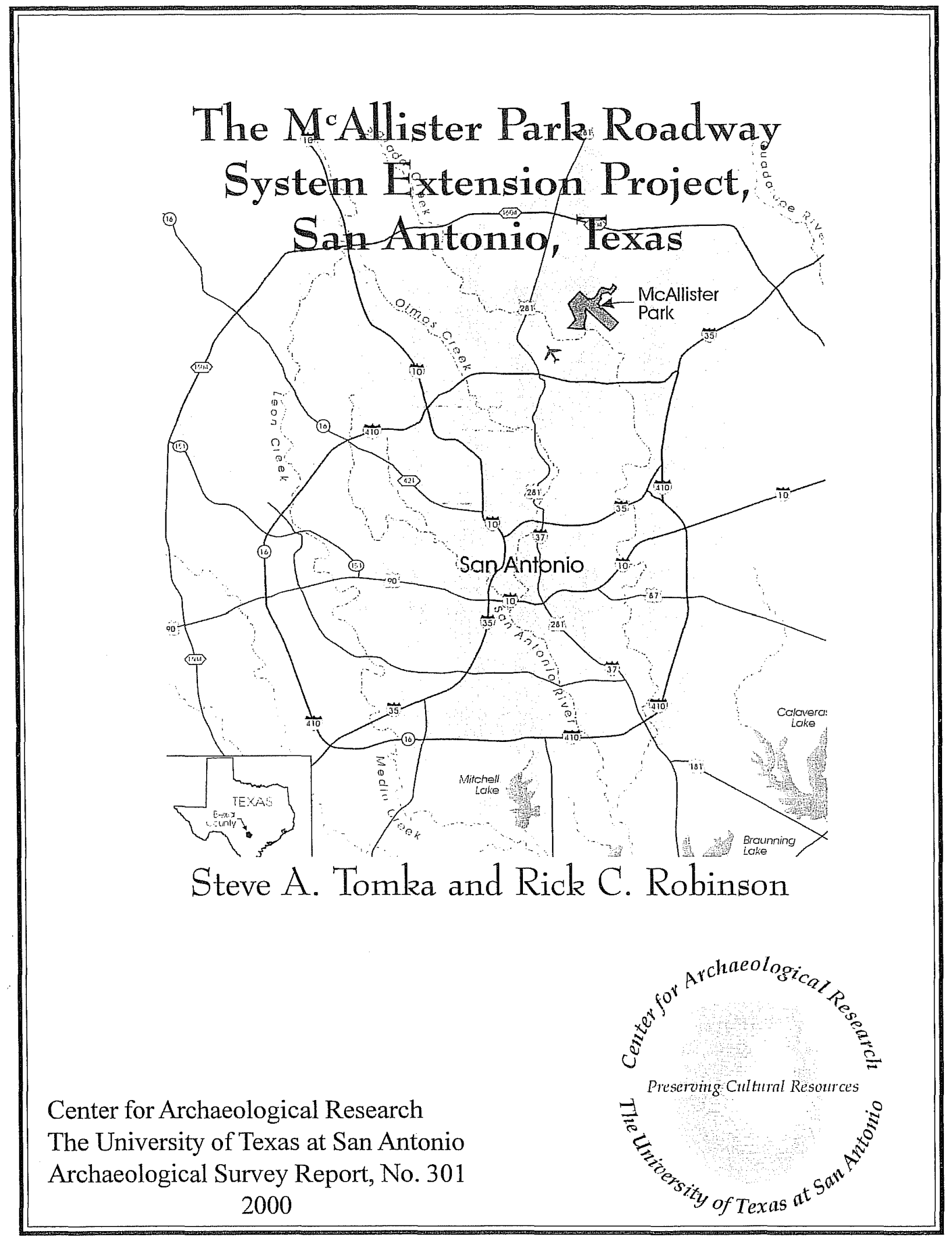





\title{
The McAllister Park Roadway System Extension Project, San Antonio, Texas
}

Steve A. Tomka and Rick C. Robinson

\author{
Robert J. Hard \\ Principal Investigator
}

Texas Antiquities Permit No. 2247

Ccopyright 2000

Center for Archaeological Research

The University of Texas at San Antonio

Archaeological Survey Report, No. 301 
The following information is provided in accordance with the General Rules of Practice and Procedure, Chapter 41.11 (Investigative Reports), Texas Antiquities Committee:

1. Type of investigation: Survey

2. Project name: McAllister Park Roadway Survey

3. County: Bexar

4. Principal investigator: Robert J. Hard

5. Name and location of sponsoring agency: City of San Antonio, Parks and Recreation Department, 506 Dolorosa, San Antonio, Texas 78283-3966

6. Texas Antiquities Permit No.: 2247

7. Published by the Center for Archaeological Research, The University of Texas at San Antonio, 6900 N. Loop 1604 W., San Antonio, Texas 78249-0658, 2000

A list of publications offered by the Center for Archaeological Research is available. Call (210) 458-4378; write to the Center for Archaeological Research, The University of Texas at San Antonio, 6900 N. Loop 1604 W., San Antonio, Texas 78249-0658; e-mail to car@lonestar.utsa.edu; or visit CAR's web site at http://car.utsa.edu. 


\begin{abstract}
The Center for Archaeological Research (CAR) of The University of Texas at San Antonio (UTSA) conducted an intensive pedestrian survey and subsurface testing for cultural resources along the proposed extensions to the McAllister Park road system, in McAllister Park, located in northeast San Antonio, Bexar County. The proposed extension impacts two sections of McAllister Road: the extreme western portion adjacent the park entrance at Jones Maltsberger, and its southern section exiting at Starcrest Drive. The project was carried out between September 16 and October 21, 1999, under contract with the City of San Antonio Parks and Recreation Department and under Texas Antiquities Permit Number 2247. The original project consisted of two tasks: 1) pedestrian survey of the proposed right-of-way, and 2) the documentation and recording of newly discovered archaeological sites. Following the identification of 41BX1412, in consultation with members of the Texas Historical Commission (THC) and Steve Uncapher from the Parks and Recreation Department of the city of San Antonio, the original project scope was extended to also include the testing of the site to more accurately determine the nature of the archaeological components identified during initial site recording. Sites 41BX1410 and 41BX1411 represent small ephemeral sites with low artifact yields and very shallow deposits. Site 41BX1412 is a stratified multi-component campsite with a thin veneer of early twentieth century historic materials, a partially buried Early Archaic component, and a deeper, probably Paleoindian, component buried 50-60 cm below the surface. No in situ features have been identified during the initial testing of the site. Sites 41BX1410 and 41BX1411 are not recommended for either State Archeological Landmark designation or eligibility for listing to the National Register of Historic Places, and no additional archaeological work is recommended at these properties. 41BX1412 is recommended for designation as a State Historic Landmark and as eligible for nomination to the National Register of Historic Places.
\end{abstract}




\section{Contents}

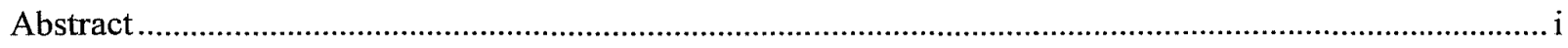

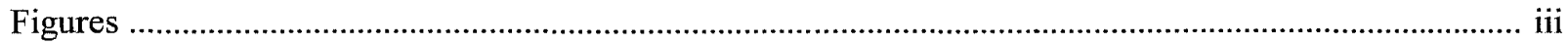

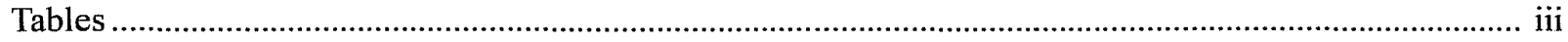

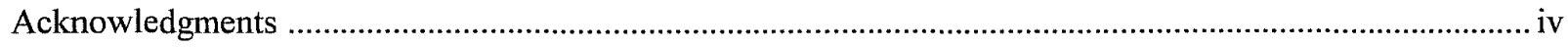

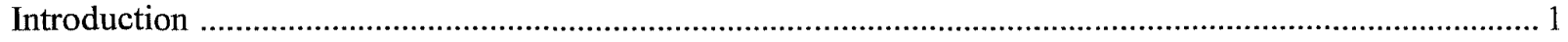

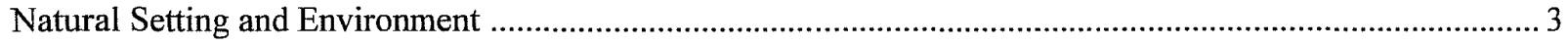

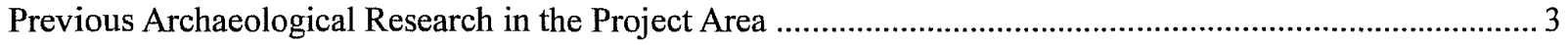

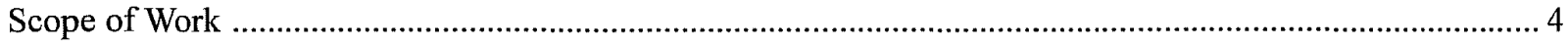

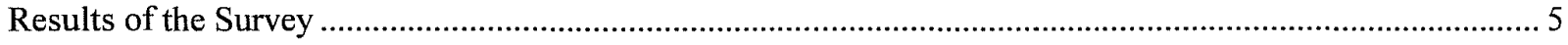

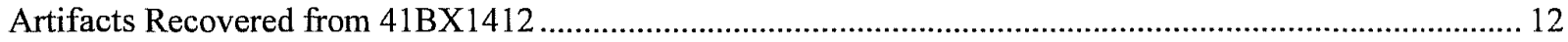

The 41BX1412 Assemblage in the Broader Early Archaic Context ....................................................22

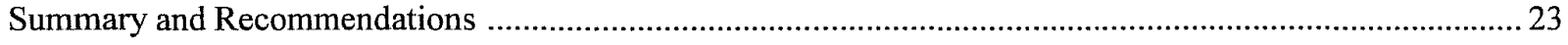

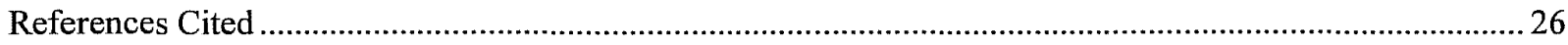

Appendix 1

Appendix 1.1 .

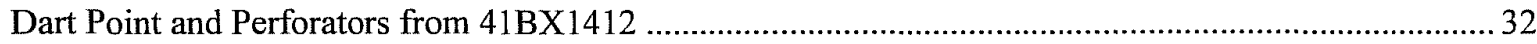

Appendix 1.2.

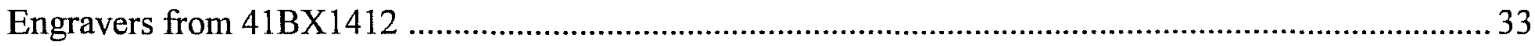

Appendix 1.3.

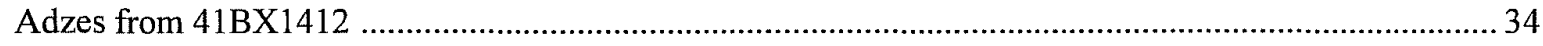

Appendix 1.4.

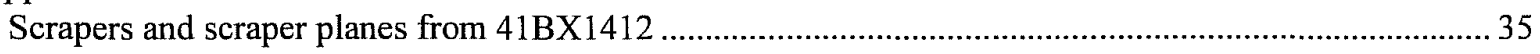

Appendix 1.5.

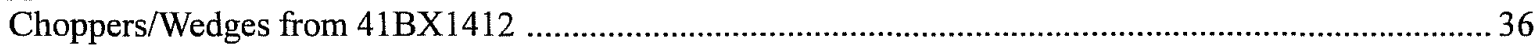

Appendix 1.6.

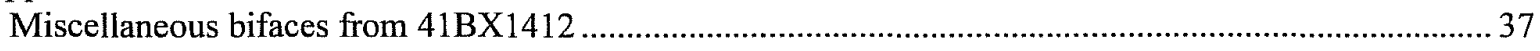

Appendix 1.7.

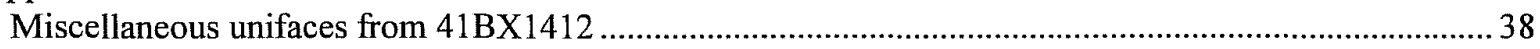

Appendix 1.8.

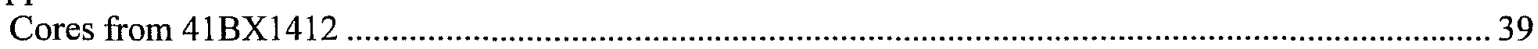




\section{Figures}

Figure 1. Location of McAllister Park within Bexar County, Texas. ............................................................. 1

Figure 2. Location of 41BX1410, 41BX1411, and 41BX1412 within the project area.................................. 2

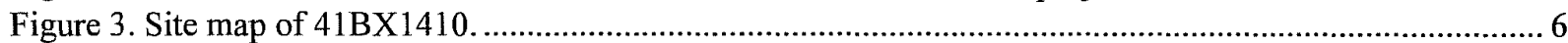

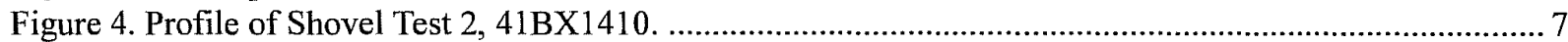

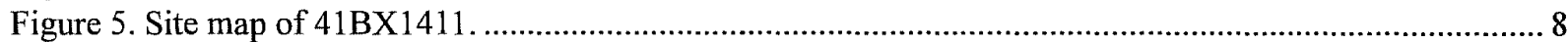

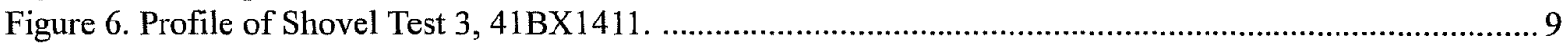

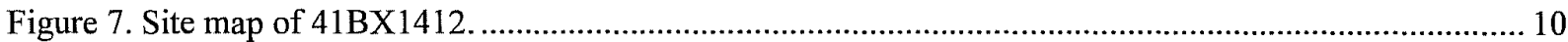

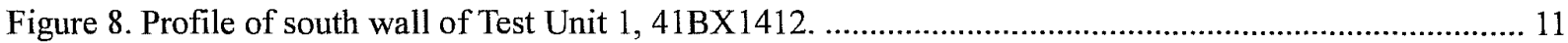

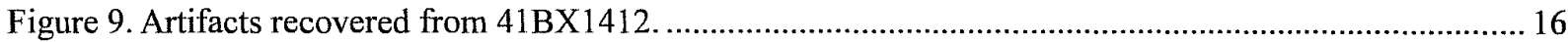

\section{Tables}

Table 1. Artifacts recovered from 41BX1412 by shovel test and test units ................................................ 12

Table 2. Artifacts recovered from STs and TUs by vertical provenience ........................................................ 13

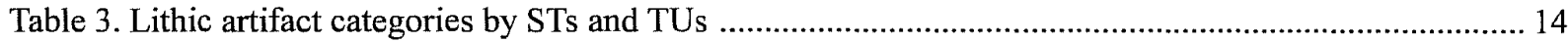

Table 4. Lithic artifact categories recovered from STs and TUs by level ................................................... 14

Table 5. Unmodified lithic debitage recovered from 41BX1412 …........................................................... 19

Table 6. Mean and standard deviation of debitage maximum dimension by level within the two TUs ........... 20 


\section{Acknowledgments}

The successful completion of this project is owed in a large part to the able and hard working field crew and lab technicians that helped in the survey, testing, and laboratory processing of the materials obtained during the project. They include the following individuals: Chris Barrett, Chris Cooley, Carol Leezer, Preston McWhorter, and Clemente Murguia. Mr. Steve Uncapher, of the Parks and Recreation Department of the city of San Antonio, facilitated the project in many ways. We gratefully acknowledge the support of CAR staff, in particular director Robert J. Hard, small project coordinator Cindy Tennis, and technical editors Maryanne King and Johanna Hunziker. Chris Butler mapped 41BX1412 and drafted the site map. Bruce Moses produced the remaining figures. Their help is greatly appreciated. 


\section{Introduction}

\section{Steve A. Tomka}

The Parks and Recreation Department of the city of San Antonio contacted the Center of Archaeological Research (CAR) of The University of Texas at San Antonio (UTSA), to identify and record any significant cultural deposits that may be affected by additions to the existing McAllister Park road system (Figures 1 and 2). These additions are planned at the extreme western and southern sections of the road system. The western extension is planned near the entrance to McAllister Park, where Main Road leads into the park off Jones Maltsberger Road. Here, immediately east of the park entrance, Main Road will be redirected to the northeast to connect with G Road and in turn reconnect with and continue on Main Road through the center of the park (Figure 2). The southern extension is planned to connect with Bee Tree Drive and continue southeast before turning southsouthwest to emerge on Starcrest Drive (Figure 2). The portion of Bee Tree Drive extending west of the proposed extension will remain in use. These planned

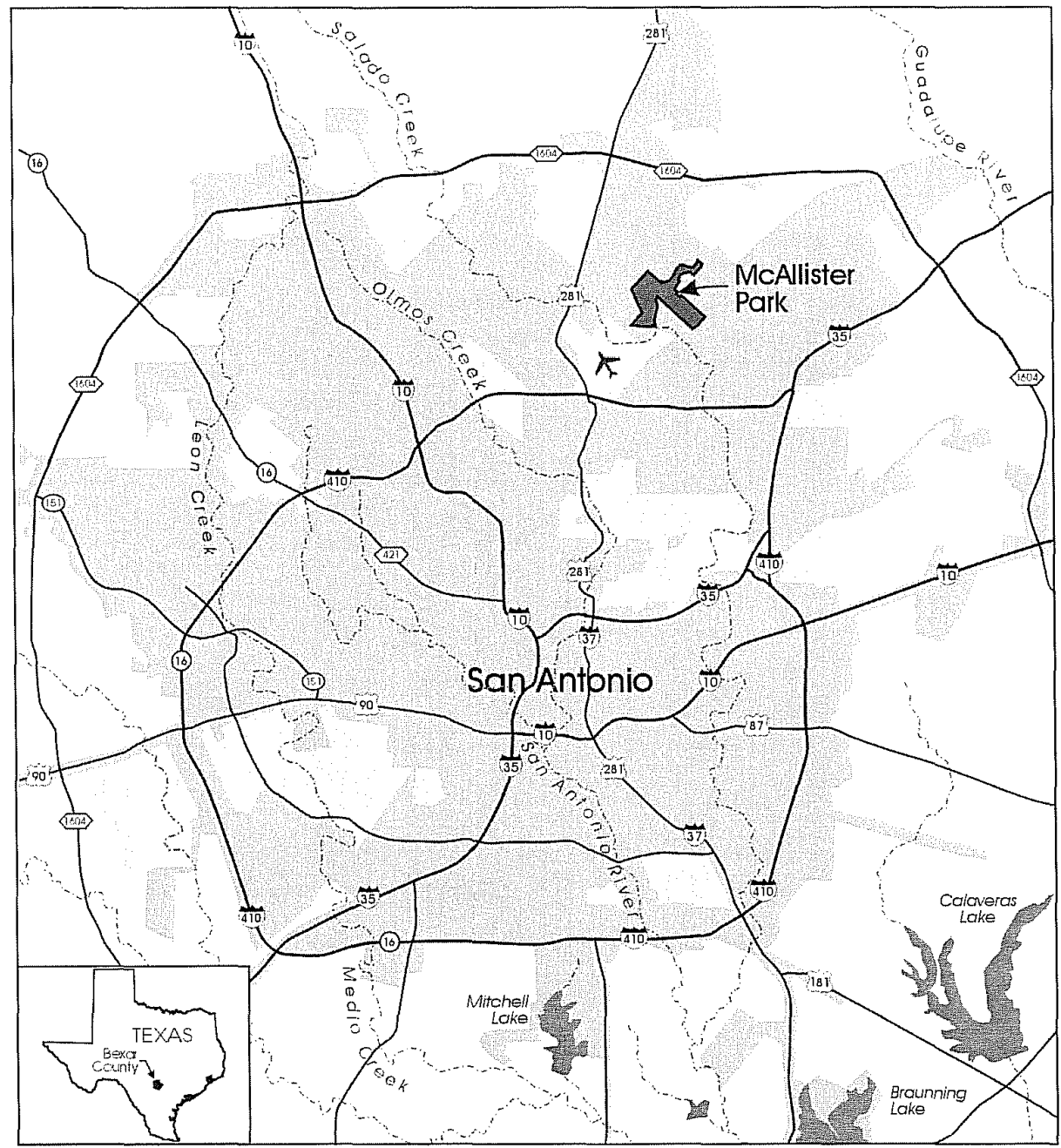

Figure 1. Location of McAllister Park within Bexar County, Texas. 
This page has been

redacted because it

contains restricted

information. 


\section{Natural Setting and Environment}

\author{
Rick C. Robinson
}

McAllister Park is in northeast Bexar County (Figure 1) and lies between two major physiographic zones: the Blackland Prairie, and the Balcones Canyonlands (LBJ School of Public Affairs 1978). The major drainage within the park is Mud Creek, a tributary of Salado Creek that empties into the San Antonio River (Potter et al. 1995:7).

The soils within the project area consist of the Lewisville-Houston Black association and include Trinity clays, Frio clay loams, Tarrant calcareous clay, and Lewisville silty clays (Taylor et al. 1962:Sheet 29). Trinity and Frio clays and clay loams tend to occur on poor- to well-drained bottom lands (e.g., Mud Creek floodplain). These soils are developed from finetextured recent alluvium transported from nearby slopes. The thickness of the A horizon ranges from 108 to $190 \mathrm{~cm}$ (Taylor et al. 1962:113). Tarrant series calcareous clayey Lithosols have a dark grayish-brown color and develop over hard limestone in well-drained upland settings (e.g., upland settings overlooking Mud Creek) such as those found along the western edge of the project area along Jones Maltsberger Road. The thickness of the A horizon in these soils ranges from 14 to $32 \mathrm{~cm}$, and the texture ranges from clay to clay loam with numerous limestone fragments (Taylor et al. 1962:115). Lewisville silty clays have a dark grayish-brown color and develop under grassy vegetation on well-drained nearly level to gently sloping terraces above floodplains (e.g., slopes bordering high terraces of Mud Creek). The texture of these soils ranges from light clay to clay loam to silty clay, with the clay content ranging from 32 to 55 percent. The A horizon of these soils can reach a thickness of between 43 to 105 cm (Taylor et al. 1962:113).

The modern flora and fauna is transitional (Riskind and Diamond 1986:29) between the Balconian and the Tamaulipan biotic provinces (Blair 1950). These biotic zones converge on the Balcones Escarpment creating a rich environment of edible plants and game. Historic land modification and grazing have severely impacted this landscape creating a patchy mix of grasslands and woodlands (Riskind and Diamond 1986:30).

\section{Previous Archaeological Research in the Project Area}

\author{
Rick C. Robinson
}

The project area lies between the Central Texas Plateau-Prairies and the South Texas Coastal Plain archaeological subregions (Hester 1989:2). The broad outlines of the general chronological and cultural historic sequences established for these neighboring regions (Collins 1995; Hester 1995; Johnson and Goode 1994; Prewitt 1981, 1983) are also applicable to the project area. Although some discrepancies still remain (Collins 1995; Johnson 1986; Johnson and Goode 1994), the commonly accepted regional chronology consists of:

$$
\begin{aligned}
& \text { Paleoindian (11,000-6500 B.C.); } \\
& \text { Early Archaic (6500-3500 B.C.); } \\
& \text { Middle Archaic (3500-2300 B.C.); } \\
& \text { Late Archaic (2300 B.C.-A.D. 750); and } \\
& \text { Late Prehistoric (A.D. 750-1700); } \\
& \text { (Johnson and Goode 1994). }
\end{aligned}
$$

The rich archaeological record of Bexar County contains components and sites representative of each of these time periods. In addition, projects such as the recent investigations at Camp Stanley (Kibler et al. 1998; Scott et al. 1998), and previously investigated sites such as 41BX300 (Katz 1987), and 41BX228 (Black and McGraw 1985) provide a glimpse of the Prehistoric archaeological sites expected within the project area. Based on these studies, it is possible to suggest that residential camps, lithic procurement, and specialized resource processing sites may all be encountered within the project area. The most likely locations for archaeological sites should be near springs or on high terraces bordering nearby drainages (Potter et al. 1995:34-36).

The project area itself is found within McAllister Park, a 714-acre parcel of land acquired in 1966. The purpose of this purchase by the city of San Antonio was to develop a recreational facility that would later become known as McAllister Park. In 1972, Anne Fox, working under the direction of the Texas Archeological Salvage Project, was given permission by the city of San Antonio Parks and Recreation Department to 
conduct a pedestrian survey to assess the presence of any archaeological sites within the park's boundary. Three sites were identified on the east bank of Mud Creek. They consisted of a habitation site (41BX172), a lithic scatter (41BX173), and a lithic procurement site (41BX174, Fox 1973:3-5). The first two sites lie some 400 and 900 feet to the south of the project area, respectively, along Bee Tree Drive within the park boundaries. Site $41 \mathrm{BX} 174$ is about 800 feet east of the project area.

An additional survey relevant to the present project was conducted by CAR personnel between December 1976 and February 1977, at the request of the city of San Antonio. The purpose of the survey was to identify and record the cultural resources that would be impacted by future development of the city's wastewater treatment project (Fox 1977). The project area included portions of Mud Creek within and outside of the park's boundaries. A number of Prehistoric archaeological sites were recorded during the survey, including 41BX353, on the west bank of Mud Creek, and 41BX354, just north of the Lockhill-Selma Road also on Mud Creek (Fox 1977:12-15). Both sites appeared to be habitation sites containing scattered burned rock, lithic debitage, bifacial and unifacial tools, and projectile points (Fox 1977:12-15). Since then, no other archaeological investigations have been conducted within the park's boundaries or its immediate vicinity.

\section{Scope of Work}

\author{
Steve A. Tomka
}

The initial goal of the pedestrian survey of the McAllister Park Project was to identify and record all Prehistoric and Historic cultural remains that would be impacted by the proposed additions to the road system. Following the identification of three archaeological sites, the project acquired an additional goal: to assess the nature of the cultural materials contained within one of the three sites, 41BX1412.

\section{Methods}

It was recommended that a pedestrian survey be conducted along the proposed roadway to identify potential sites that may be impacted by the impending construction. The right-of-way (ROW) consisted of a 48 foot-wide (15 meters), 2.5 mile-long corridor (Figure 2 ). Since a portion of the new roadway was to incorporate existing paved roads (i.e., Main Road and G Road), this section was to be excluded from the survey. Given good to excellent surface visibility along the project area and the width of the ROW, it was decided to position one team member in the center of the ROW and one each some 24 feet ( 7.5 meters) on either side. The backdirt from animal burrows and the banks of erosional cuts were inspected for cultural materials. Given the excellent surface visibility and thin topsoils, it was felt that shovel testing was warranted only when and where cultural materials were noted on surface. Artifact concentrations identified during the survey were to be flagged and noted on the topographic sheet. At the end of the survey, crews returned to each concentration to define site boundaries, assess the depth and integrity of the cultural remains through shovel testing, and complete a sketch map and the Archaeological Site Data Form. Artifacts encountered in all shovel tests (STs) were collected and returned to the CAR laboratory for processing and analysis. With the exception of surface artifacts on 41BX1412, all other artifacts noted on surface were described in the field but left on-site. 
Only temporal diagnostics were collected from surface during the initial site recording of 41BX1412. Once the need arose to more fully assess the nature of the cultural materials from the site, it was decided that a representative sample of all surface artifacts would be collected. Prior to the surface collection, an intensive surface reconnaissance of the entire site was conducted to identify all visible artifacts. Each artifact was numbered and flagged to allow easy relocation for point plotting. An infield analysis was conducted of each of the flagged artifacts, and following mapping a representative sample was collected for more detailed analysis and curation.

During the initial survey four STs were excavated to establish the depth of the cultural materials. To more accurately assess the nature of the cultural deposits, 16 additional STs and two $1 \times 1$ meter test units (TUs) were dug following consultation with Mark Denton of the THC and Steve Uncapher of the Parks and Recreation Department.

The south wall of each test unit was profiled and photographed. The site boundaries and surface artifact distribution were mapped with a Total Data Station (TDS). Also, an interview conducted with Marvin Klar, son of the original land owner, provided helpful information concerning the land use history of the area prior to its purchase by the city of San Antonio.

\section{Results of the Survey}

\author{
Steve A. Tomka and Rick C. Robinson
}

Three sites were identified during the pedestrian survey (Figure 2). 41BX1410 and 41BX1411 are located along the western margin of the project area. 41BX1412 is located on a upland terrace of Mud Creek, in the central portion of the project area, some 400 feet (125 meters) northeast of 41BX172 recorded by Fox (1973).

\section{$41 B \times 1410$}

The site is located approximately 640 feet (200 meters) northeast of the park's entrance at Jones Maltsberger (Figure 3). It covers approximately $162 \mathrm{~m}^{2}(18 \times 9$ meters). A recently built manhole is in the west-central part of the site. Two light scatters of artifacts, consisting of three secondary flakes, a single primary flake, a unifacially retouched flake, and two early reduction stage bifaces, were observed on surface. A small number $(n=6)$ of additional flakes were scattered north and south of the two clusters on deflated surfaces with exposed limestone. The site boundary was established based on the surface distribution of artifacts. Three STs were excavated adjacent to surface artifacts and in areas with some topsoil. Two of the units reached a depth of $10 \mathrm{~cm}$ bs, the third penetrated to $15 \mathrm{~cm}$ bs before encountering limestone bedrock. Cultural materials, consisting of four tertiary flakes and seven modern glass fragments, were recovered from ST 1, Level 1 (0-10 cm below surface [bs]). The STs revealed dark brown sandy clay-loam with underlying limestone bedrock (Figure 4). The sandy clay-loam ranged from $3-17 \mathrm{~cm}$ in depth. No additional STs were excavated at this site. 


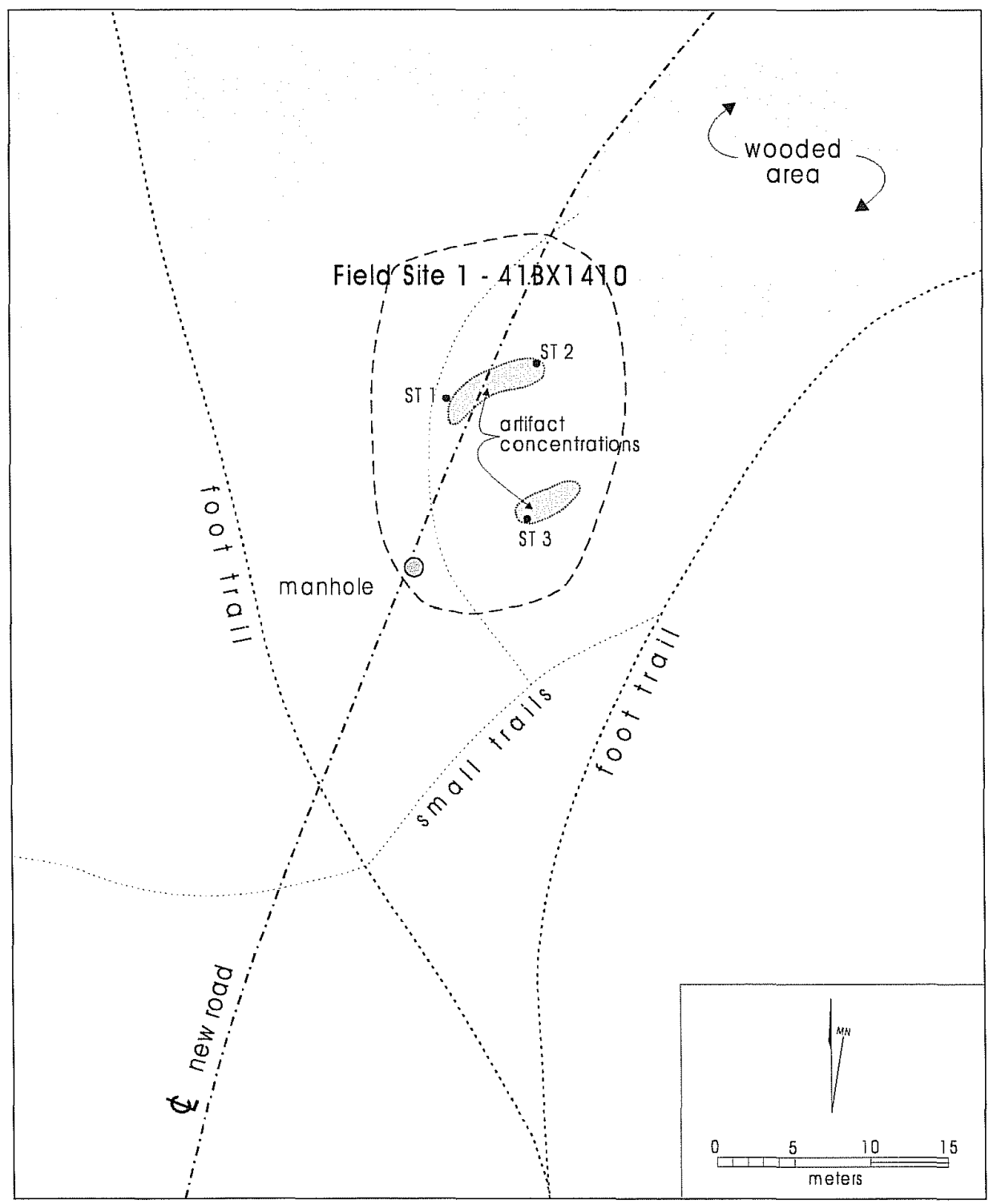

Figure 3. Site map of $41 B X 1410$. 


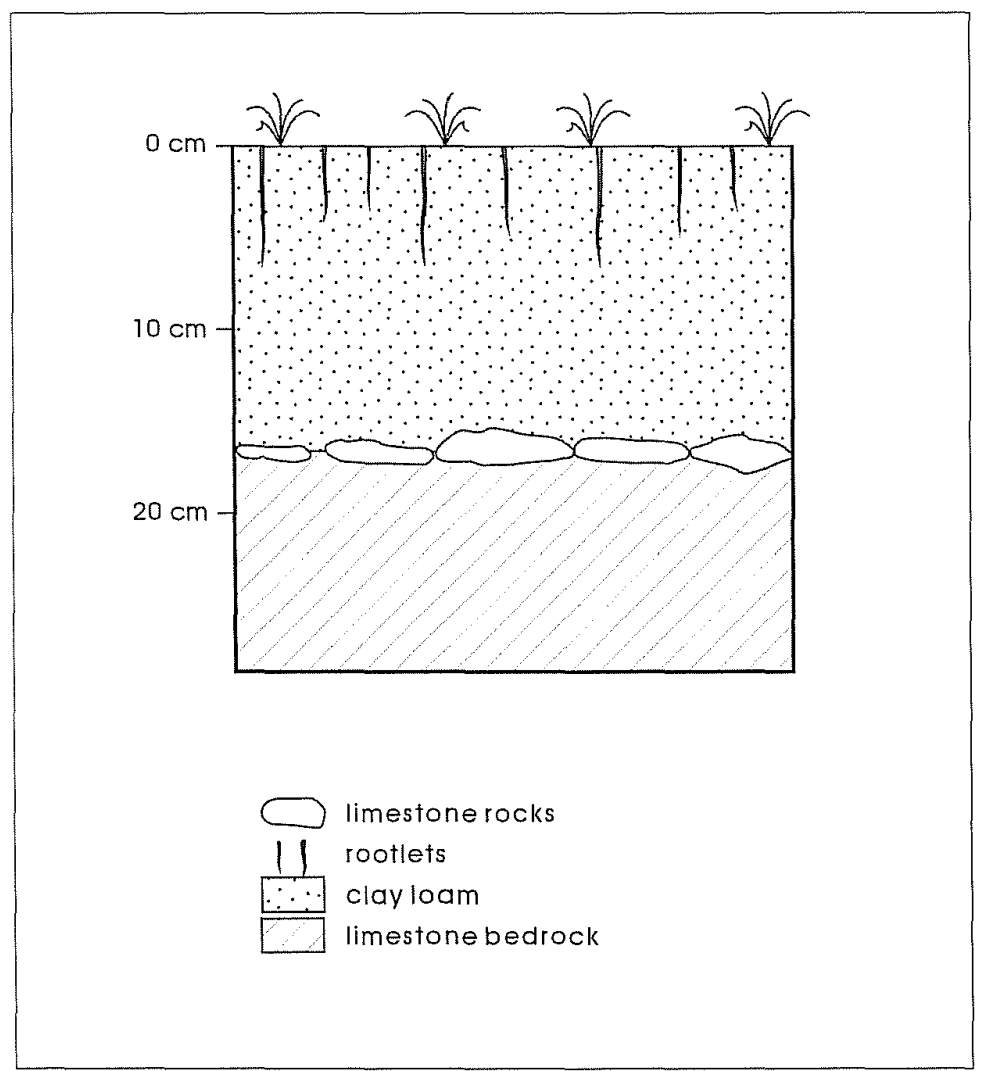

Figure 4. Profile of Shovel Test 2, 41BX1410.

\begin{abstract}
41BX1411
This site is located approximately 240 feet ( 75 meters) east of 41BX1410 in an eastward-sloping upland setting (Figure 5). The area is surrounded by modern picnic sites and is crisscrossed by nature trails. Thin soils are present within the wooded area, while limestone bedrock is exposed in portions of the footpath running along the western edge of the site. A large tertiary flake, a multidirectional and an unidirectional core, and an early reduction stage biface were observed on surface. The site boundary reflects the
\end{abstract}

sparse and dispersed distribution of the lithic artifacts. The site covers approximately $130 \mathrm{~m}^{2}(13 \times 10$ meters $)$. Three STs were excavated to a depth of $20 \mathrm{~cm}$ bs. Four tertiary flakes were recovered (ST 1, Level 2 $\mathrm{n}=1$; ST 2, Level $2 \mathrm{n}=1$; and ST 3, Level $1 \mathrm{n}=2$ ). The soils consisted of shallow dark brown sandy clay-loam (0-20 cm bs) with underlying limestone bedrock (Figure 6). Given the low material recovery and shallowness of the site, no additional STs were excavated. 


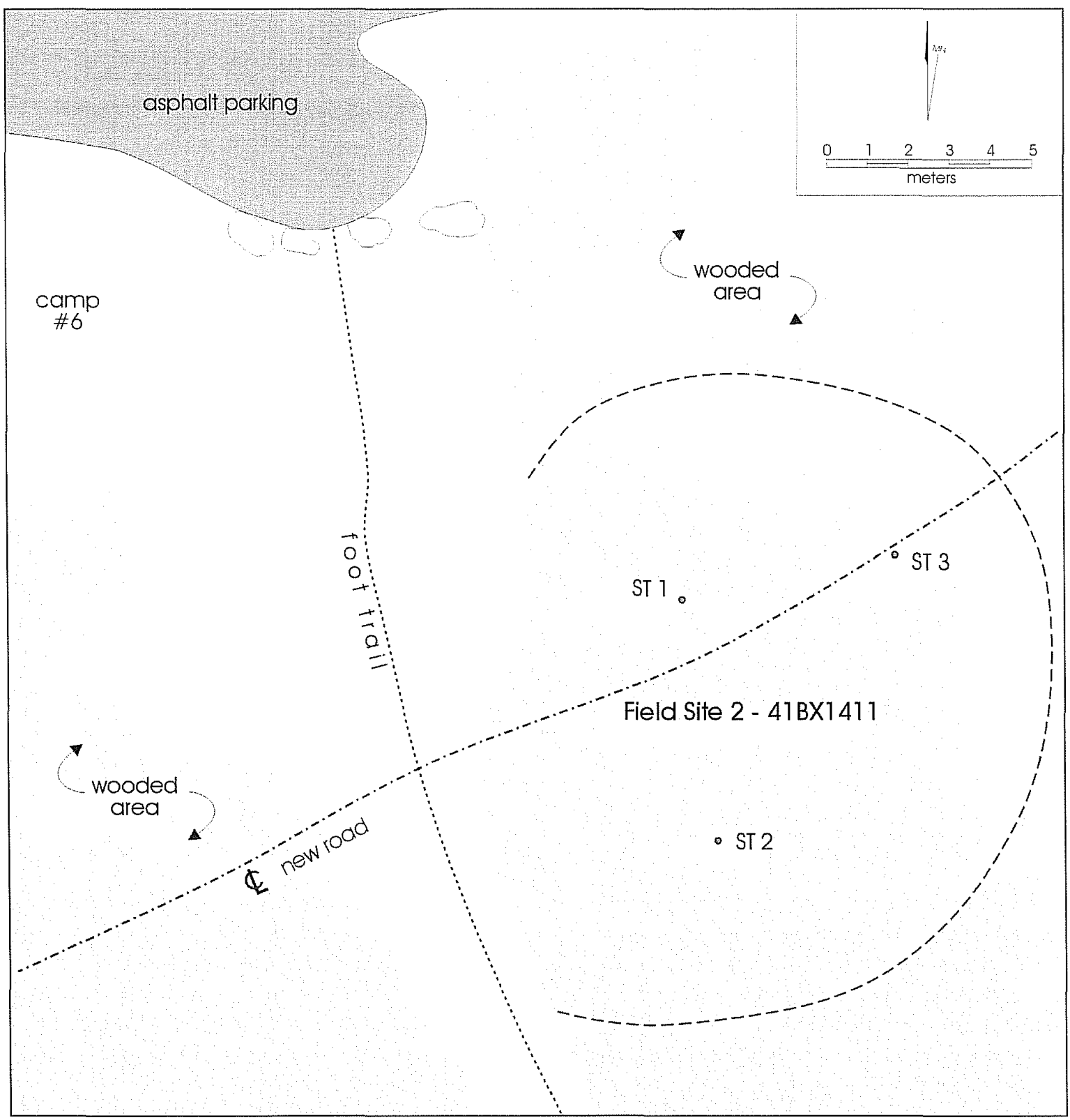

Figure 5. Site map of $41 B X 1411$. 


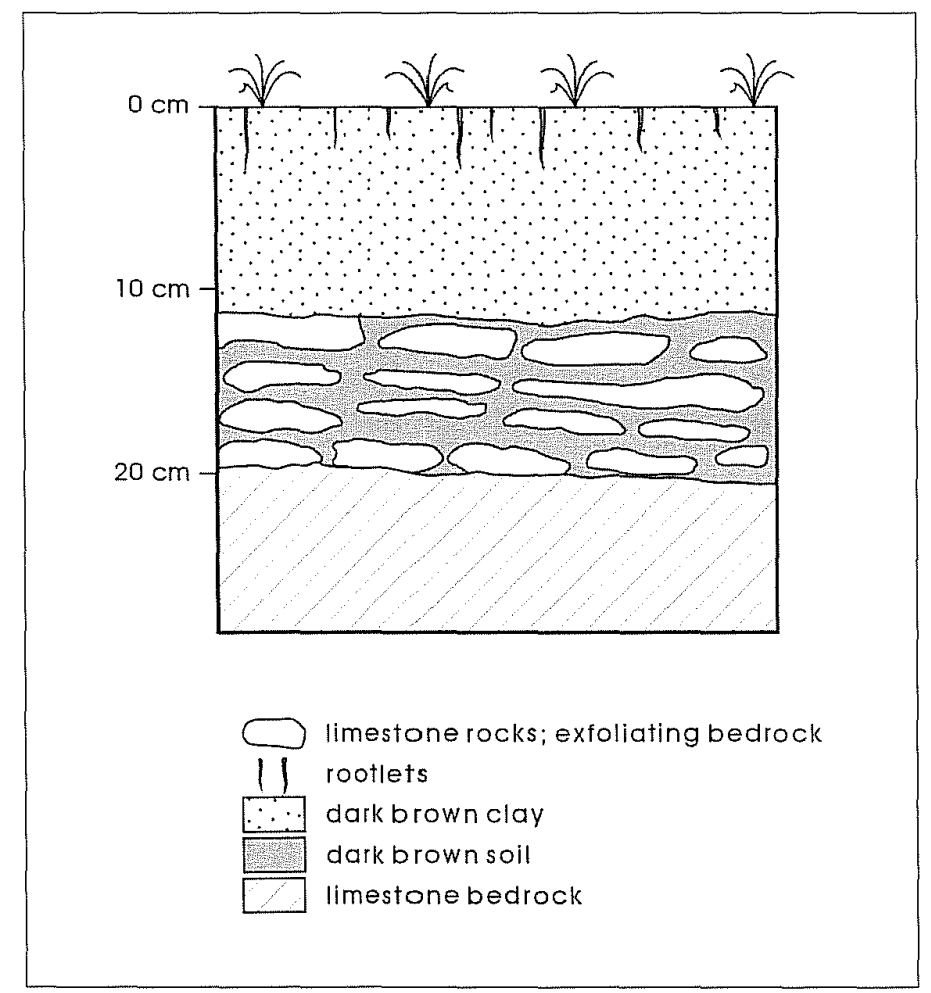

Figure 6. Profile of Shovel Test 3, 41BX1411.

\begin{abstract}
41BX1412
Site $41 B X 1412$ is a multi-component site which is located on an upland terrace on the south bank of Mud Creek (Figure 7). It is bisected by a sharp turn in Bee Tree Drive. Surface inspection of the vicinity indicated that a light scatter of artifacts extended immediately north of Bee Tree Drive. The cleared portion of the ROW immediately south of the road also contained a light scatter of artifacts. However, the densest artifact scatter was found within a lightly wooded area some 20 feet (6.25 meters) south of the road. Material densities dropped rapidly further south as one approached a barbed wire fence that delimited the approximate southern boundary of the site. The site boundary reflects the surface distribution of artifacts, it covers approximately $5,000 \mathrm{~m}^{2}(100 \times 50$ meters $)$.

The majority of the surface cultural materials consisted of Prehistoric chipped lithics although a light veneer of Historic materials was also scattered across the site.
\end{abstract}

A cattle trough and a small concrete structure that served as the base of a water tank are located immediately east of the ROW. These facilities and the Historic materials were part of the Ed Klar homestead when it was purchased in 1937. Interviews with $\mathrm{Mr}$. Marvin Klar, son of Ed Klar, indicated that a small farmhouse was already present at the location at the time of purchase. Following the purchase, a dairy farm was established on the site, and additional rooms were added to the original building. Sometime later, a barn was built on the premises. The southern portion of 41BX1412 was never plowed but it may have been used as a cattle corral or a pigpen. The dairy farm ceased operations in the late 1960s when the city of San Antonio purchased the property.

At the time of discovery, the surface of the site was littered with a large number of primary and secondary flakes, numerous bifaces, cores, barbed-wire pieces, bottle fragments, and unidentifiable metal fragments. The Historic materials inspected in the field date from 
This page has been

redacted because it

contains restricted

information. 
the 1930 s to the present. A thorough search of the site for temporal diagnostic artifacts yielded three Guadalupe adzes, an early split stem dart point, and a drill made on a recycled lanceolate dart point with Paleoindian flaking characteristics.

Initially, four STs were excavated to establish the depth of the cultural materials (Figure 7). The shovel tests were excavated to a depth of $50 \mathrm{~cm}$ bs where excavation terminated because of reduced artifact recovery and/or the total absence of artifacts. These STs revealed cultural deposits extending to a depth of 60 $\mathrm{cm}$ bs (see below). Based on the temporal diagnostics recovered from surface, and the depth and richness of the deposits, and in consultation with Mark Denton of the Department of Antiquities Protection, THC, it was decided that further testing would be necessary to more clearly establish the depth and subsurface horizontal distribution of the deposits. Steve Uncapher of the San Antonio Parks and Recreation Department was informed of the need for additional work and consulted regarding the relocation of the planned road to prevent further impacts to the site. Given the presence of soccer fields, parking lots, and existing roads within the vicinity of the site such relocation was not feasible and plans were developed for additional investigations of the site.

Sixteen STs and two $1 \times 1$ meter TUs were excavated as part of this effort (STs 5-20; Figure 7). Each of these units was excavated to a depth of between 40 to $60 \mathrm{~cm}$ bs, where excavations stopped due to the limestone bedrock. In addition, an extensive surface collection of Prehistoric artifacts was made to better document technological features of the assemblage. The two TUs and 20 STs revealed that the soil matrix in the upper $40-45$ centimeters consisted of a dark brown clay-loam (10YR3/1), while a lighter grayishbrown (10YR3/3) silty-clay characterized the lower 10-15 centimeters sitting on exfoliating limestone bedrock (Figure 8 ). No obvious soil disturbances were evident during excavation.

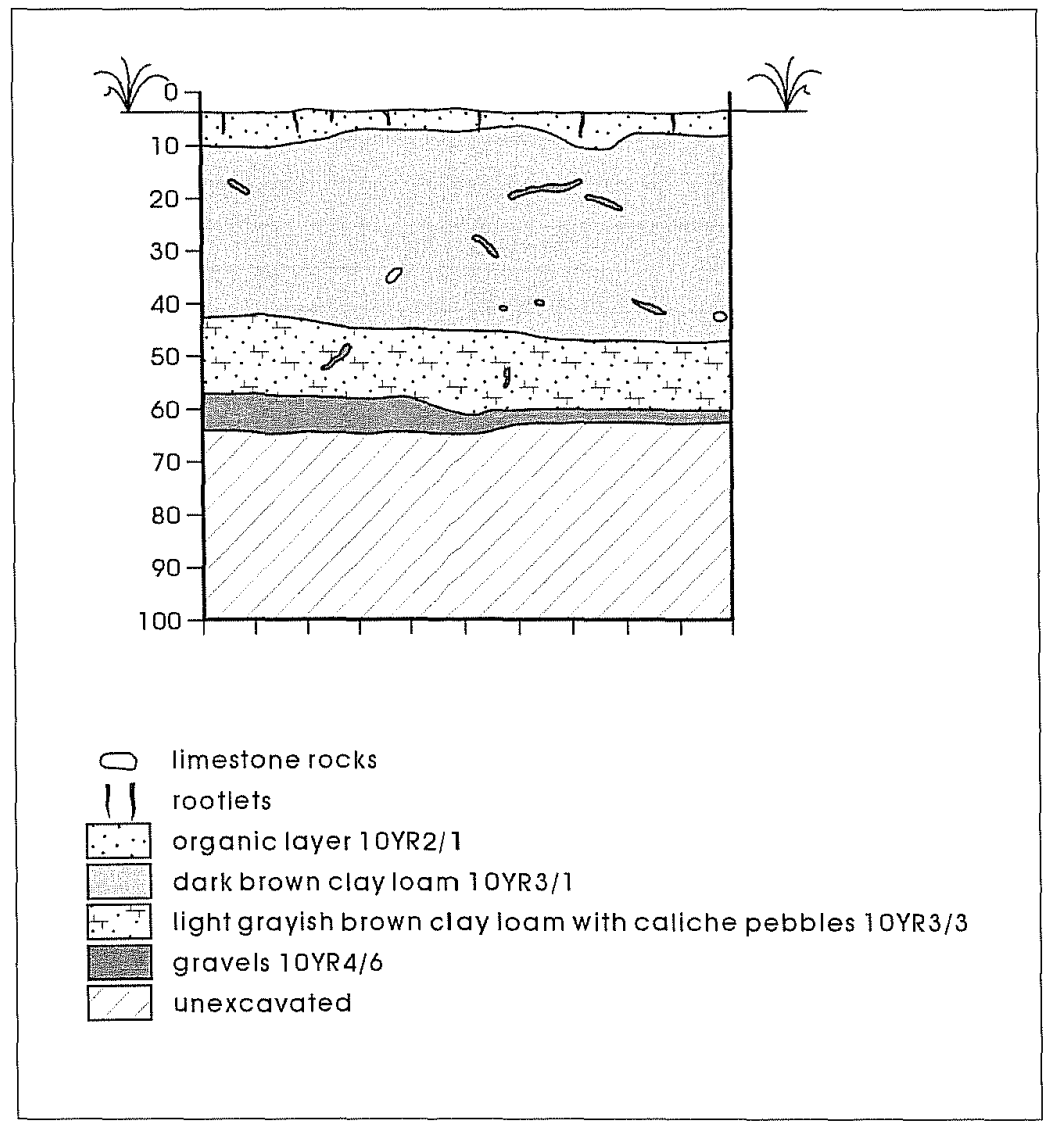

Figure 8. Profile of south wall of Test Unit 1, 41BX1412. 


\section{Artifacts Recovered from 41BX1412}

\author{
Steve A. Tomka
}

A total of 870 artifacts were recovered from 41BX1412 (Table 1). Of these, $779(89.5 \%)$ are Prehistoric artifacts and $91(10.5 \%)$ are Historic materials. The majority of the Prehistoric artifacts came from the TUs and the general surface collection. Most of the Historic artifacts were encountered in STs and TUs.

The vertical distribution of materials indicates that both Prehistoric and Historic materials tend to decrease with depth (see ST artifacts in particular, Table 2). The presence of small numbers of Historic artifacts (e.g., wires, glass) in Levels 4-6 is most likely due to the downward movement of artifacts as a result of drying-induced cracking prevalent in the clay soils of the site and bioturbation.

\section{Historic Artifacts}

The 91 Historic artifacts recovered from the site consist of fragments of wire $(n=58)$, miscellaneous unidentified metal $(n=14)$, bottle and window glass fragments $(n=7)$, ceramics $(n=5)$, barbed wire fragments $(n=3)$, a wire nail $(n=1)$, a fence staple $(n=1)$, and a fragment of an agricultural implement $(n=1)$.

The majority of these artifacts are unidentifiable nondiagnostic artifacts. However, a select number of items do offer a hint of the earliest age of the Historic occupation of the site and its vicinity. Of the five ceramic fragments, four are undecorated whitewares and one is an undecorated stoneware fragment. Whitewares are generally an indicator of nineteenth century occupation on San Antonio sites. It was not until after the Civil War that whitewares became widely available

Table 1. Artifacts recovered from 41BX1412 by shovel test and test units

\begin{tabular}{|c|c|c|c|}
\hline Provenience & $\begin{array}{c}\text { Prehistoric } \\
\text { Artifacts }\end{array}$ & $\begin{array}{l}\text { Historic } \\
\text { Artifacts } \\
\end{array}$ & Total \\
\hline General Surface & 282 & 3 & 285 \\
\hline ST 1 & 32 & 3 & 35 \\
\hline ST 2 & 1. & 3 & 4 \\
\hline ST 3 & 7 & 3 & 10 \\
\hline ST 4 & 1 & 2 & 3 \\
\hline ST 5 & 3 & 7 & 10 \\
\hline ST 6 & 6 & 5 & 11 \\
\hline ST 7 & 4. & 3 & 7 \\
\hline ST 8 & 7 & & 7 \\
\hline ST 9 & 11 & & 11 \\
\hline ST 10 & 15 & 4 & 19 \\
\hline ST 11 & 5 & & 5 \\
\hline ST 12 & 15 & 5 & 20 \\
\hline ST 13 & 3 & 1 & 4 \\
\hline ST 14 & 11 & 2 & 13 \\
\hline ST 15 & 9 & 2 & 11 \\
\hline ST 16 & 27 & 2 & 29 \\
\hline ST 17 & 10 & 4 & 14 \\
\hline ST 18 & 8 & 3 & 11 \\
\hline ST 19 & 4 & 1 & 5 \\
\hline ST 20 & 18 & & 18 \\
\hline ST Totals & 197 & 50 & 247 \\
\hline EU 1 & 66 & 11 & 77 \\
\hline EU 2 & 234 & 27 & 261 \\
\hline EU Totals & 300 & 38 & 338 \\
\hline Grand Totals & 779 & 91 & 870 \\
\hline
\end{tabular}


Table 2. Artifacts recovered from STs and TUs by vertical provenience

\begin{tabular}{|c|c|c|c|c|c|c|c|c|}
\hline & Surface (ST/EU) & Level 1 & Level 2 & Level 3 & Level 4 & Level 5 & Level 6 & Total \\
\hline \multicolumn{9}{|l|}{ ST Artifacts } \\
\hline Prehistoric & 5 & 46 & 34 & 38 & 33 & 28 & 7 & 191 \\
\hline Historic & & 25 & 8 & 8 & 3 & 3 & 3 & 50 \\
\hline \multicolumn{9}{|l|}{ EU Artifacts } \\
\hline Prehistoric & 12 & 63 & 46 & 62 & 76 & 18 & 29 & 306 \\
\hline Historic & 4 & 31 & 2 & 1 & & & & 38 \\
\hline \multicolumn{9}{|c|}{ General Surface } \\
\hline Prehistoric & 282 & & & & & & & 282 \\
\hline Historic & 3 & & & & & & & 3 \\
\hline Grand Total & 306 & 165 & 90 & 109 & 112 & 49 & 39 & 870 \\
\hline
\end{tabular}

in the San Antonio area (Tomka and Fox 1999a:29). The single undecorated stoneware fragment is probably from a cooking or storage vessel. These wares were probably locally made from the last quarter of the nineteenth century into the 1920s (Fox 1998).

The single clear bottle neck fragment collected from surface has no seams indicating that it is not machine made. It was probably mouth-blown into a mold. This manufacturing technique was in common usage at the end of the nineteenth into the early twentieth century (1870-1917, Miller and Sullivan 1984). Clear glass was not in common usage until after 1870 (Miller and Sullivan 1984).

No square nails were found. The single wire nail recovered from Level 2 of ST 3 may date from the very end of the nineteenth century to the present (Tomka and Fox 1999b:29).

The final temporal diagnostic artifact is a tooth from a harrowing machine used in a similar fashion as a plow and employed to breakup soil before planting. This type of agricultural implement was manufactured between the later part of the nineteenth and early twentieth century (1880-1920, Waynne Cox, personal communication 1999).

\section{Prehistoric Artifacts}

A total of 779 chipped lithic artifacts was recovered from 41BX1412 during surface collections, and the excavations of 20 STs and the two TUs (Table 3 ). The majority of these ( $n=497,64 \%)$ came from STs and TUs. Although a sizable proportion (38\%) of the Prehistoric materials was from the surface, the bulk of artifacts $(n=480,62 \%)$ came from below surface (Table 4).

The majority (82\%) of the collection consists of 635 pieces of unmodified lithic debitage. The remaining specimens $(n=144,18 \%)$ are categorized into the following functional groups: 1 dart point, 4 perforators, 3 scrapers and/or scraper planes, 14 engravers, 6 adzes, 12 cobble tools, and 39 cores (Tables 3 and 4). Tool function was determined by low-powered (20-80x) micro-wear analysis. Four unifacially flaked artifacts are classified as indeterminate unifaces, and 61 bifaces and biface fragments are classified as miscellaneous bifaces. Metric dimensions and observational attributes of the tools recovered from $41 \mathrm{BX} 1412$ are presented in Appendix 1. 
Table 3. Lithic artifact categories by STs and TUs

\begin{tabular}{|c|c|c|c|c|c|c|c|c|c|c|c|}
\hline Provenience & Dart Point & Perforator & Engraver & Adze & $\begin{array}{c}\text { Scraper/ Scraper } \\
\text { Plane } \\
\end{array}$ & $\begin{array}{l}\text { Chopper/ } \\
\text { Wedge }\end{array}$ & Misc. Biface & $\begin{array}{l}\text { Misc. } \\
\text { Uniface }\end{array}$ & Core & $\begin{array}{c}\text { Unmodified } \\
\text { Debitage }\end{array}$ & Totals \\
\hline General Surface & 1 & 3 & 10 & 6 & 3 & 11 & 53 & 1 & 38 & 156 & 282 \\
\hline ST 1 & & & & & & & & & & 32 & 32 \\
\hline ST 2 & & & & & & & & & & 1 & 1 \\
\hline ST 3 & & 1 & & & & & & & & 6 & 7 \\
\hline ST 4 & & & & & & & & & & 1 & 1 \\
\hline ST 5 & & & & & & & & & & 3 & 3 \\
\hline ST 6 & & & & & & & & & & 6 & 6 \\
\hline ST 7 & & & & & & & & & & 4 & 4 \\
\hline ST 8 & & & & & & & & & & 7 & 7 \\
\hline ST 9 & & & & & & & & & & 11 & 11 \\
\hline ST 10 & & & & & & & & & 1 & 14 & 15 \\
\hline ST 11 & & & & & & & & & & 5 & 5 \\
\hline ST 12 & & & & & & 1 & & & & 14 & 15 \\
\hline ST 13 & & & & & & & & & & 3 & 3 \\
\hline ST 14 & & & & & & & & & & 11 & 11 \\
\hline ST 15 & & & & & & & 1 (surf.) & & & 8 & 9 \\
\hline ST 16 & & & & & & & 1 & & & 26 & 27 \\
\hline ST 17 & & & & & & & 2 & & & 8 & 10 \\
\hline ST 18 & & & & & & & & & & 8 & 8 \\
\hline ST 19 & & & & & & & & & & 4 & 4 \\
\hline ST 20 & & & & & & & & 1 & & 17 & 18 \\
\hline ST Totals & & 1 & & & & 1 & 4 & 1 & 1 & 189 & 197 \\
\hline EU 1 & & & 3 & & & & 2 (1 surf.) & & & 61 & 66 \\
\hline EU 2 & & & 1 & & & & 2 & 2 & & 229 & 234 \\
\hline EU Totals & & & 4 & & & & 4 & 2 & & 290 & 300 \\
\hline Grand Totals & 1 & 4 & 14 & 6 & 3 & 12 & 61 & 4 & 39 & 635 & 779 \\
\hline
\end{tabular}

\section{Dart Point}

A single Uvalde projectile point (Turner and Hester 1993) was recovered from the surface. It has an expanding stem, a concave to U-shaped base, strong shoulders, a triangular blade, and slightly ground stem edges (Figure 9a). An impact scar is present on the tip and one ear is broken. Morphologically, the specimen also fits other Early Archaic points that have been lumped into the broad "Early Corner-Notched" category (e.g., early corner-notched, Variety 2 from the La Jita Site, Hester 1971:Figure 10, m-s; Sorrow et al. 1967:Figure 12, a-c).

Table 4. Lithic artifact categories recovered from STs and TUs by level

\begin{tabular}{|c|c|c|c|c|c|c|c|c|c|c|c|}
\hline Provenience & Dart Point & Perforator & Engraver & Adze & $\begin{array}{c}\text { Scraper/ Seraper } \\
\text { Plane }\end{array}$ & $\begin{array}{c}\text { Chopper/ } \\
\text { Wedge }\end{array}$ & Misc. Biface & $\begin{array}{c}\text { Misc. } \\
\text { Uniface }\end{array}$ & Core & $\begin{array}{c}\text { Unmodified } \\
\text { Debitage }\end{array}$ & Totals \\
\hline Surface & 1 & 3 & 10 & 6 & 3 & 11 & 55 & 1 & 38 & 171 & 299 \\
\hline Level 1 & & & 1 & & & 1 & 2 & 1 & & 104 & 109 \\
\hline Level 2 & & 1 & & & & & 2 & & 1 & 76 & 80 \\
\hline Level 3 & & & & & & & 1 & & & 99 & 100 \\
\hline Level 4 & & & 2 & & & & & 1 & & 106 & 109 \\
\hline Level 5 & & & 1 & & & & 1 & & & 44 & 46 \\
\hline Level 6 & & & & & & & & 1 & & 35 & 36 \\
\hline Totals & 1 & 4 & 14 & 6 & 3 & 12 & 61 & 4 & 39 & 635 & 779 \\
\hline
\end{tabular}




\section{Perforators}

Four perforators have been identified in the collection. Based on the thickness and width of their working tips, three are classified as reamers, tools employed in enlarging holes. One specimen is a drill employed in making rather than simply enlarging existing holes.

The three reamers form a morphologically homogeneous group. All are made on thick hard hammerstone flakes by unifacially flaking the broad working tip on the distal end of the blank (Figure 9b). One of the three specimens is made on a heavily patinated recycled hard hammerstone flake. The working tip is shaped by the alternate unifacial flaking of the tool's edges. The manufacture flake scars are unpatinated. The two other reamers also lack patina. Two of the reamers were recovered on surface, while the recycled specimen comes from Level 2 of ST 3.

The single drill from the site was found on surface at the edge of the treeline adjacent Bee Tree Drive. It represents a dart point recycled into a drill (Figure $9 \mathrm{c})$. The entire artifact is heavily patinated suggesting that the reworking occurred soon after the original manufacture of the specimen. The two long base thinning flakes, the execution of the flaking on the faces of the specimen, the wide $(34 \mathrm{~mm})$ and thick $(9 \mathrm{~mm})$ yet lenticular cross-section of the specimen, and remnants of grinding on the partially reflaked stem edges and base are consistent with Paleoindian flaking characteristics (see Clovis points, Howard 1990). In summary, the morphological and flaking characteristics and the heavy patina present on the specimen suggest strong affinities to a Paleoindian projectile point.

\section{Engravers}

The majority $(n=10)$ of the 14 gravers from the site are surface finds. Based on the degree of retouch that has gone into their manufacture, they can be divided into three categories: four are expedient gravers that represent the utilization of fortuitous sharp corner(s) of a flake blank; nine were made by the minimal retouch of one or more of the edges of the blank to create a pointed graving tip; and one specimen has one formal and a minimally retouched working tip. The formal graver tip is made by substantially flaking the edge of the blank to define a sharp graving tip.

Two of the expedient gravers are heavily patinated tertiary flake fragments employed as gravers. Multiple burin scars off the graving tips indicate repeated resharpenings. The remaining two expedient gravers are secondary hard hammerstone flake fragments with sharp, pointed, corners employed as gravers. One of these two has two repeatedly resharpened (i.e., burinated) graver tips (Figure 9d, Specimen 208).

Minimally retouched gravers are made on hard hammerstone flake blanks. The working tips are commonly created by deeply notching one or two areas adjacent a natural protrusion along the flake's edges (Figure 9e; Specimen 66). In general, elongated flakes were chosen as blanks ( 7 of $9,78 \%$ ), although two are made on short, wide flakes. On one of these, the graver tip is made by minimally retouching the corner of the distal end and the adjacent lateral edge of the blank (Figure 9f; Specimen 249). This manufacture technique, and the resulting morphology, are reminiscent of "spurred end scrapers" commonly found in Folsom assemblages (Boldurian 1990:Figure 42).

The final graver has two working tips. The formal tip is made by the heavy retouch of the distal end of a secondary flake blank into a pointed working tip. The minimally retouched working tip was made by retouching an additional edge adjacent the corner of the flake (Figure 9g; Specimen 139). The formally manufactured working tip was broken in manufacture, while the graver tip minimally retouched later is complete.

\section{Adzes}

Of the six specimens recovered from the site, five are identified as Guadalupe adzes (Black and McGraw 1985 ), and one is a minimally retouched adze that shares some morphological affinities to the type. Guadalupe adzes are common in Bexar County, but their distribution is much broader encompassing the San Antonio and Guadalupe River drainages along the Edwards Escarpment and onto the Coastal Plains region, and even extending along the middle reaches of the Rio Grande Valley. Although few specimens have 


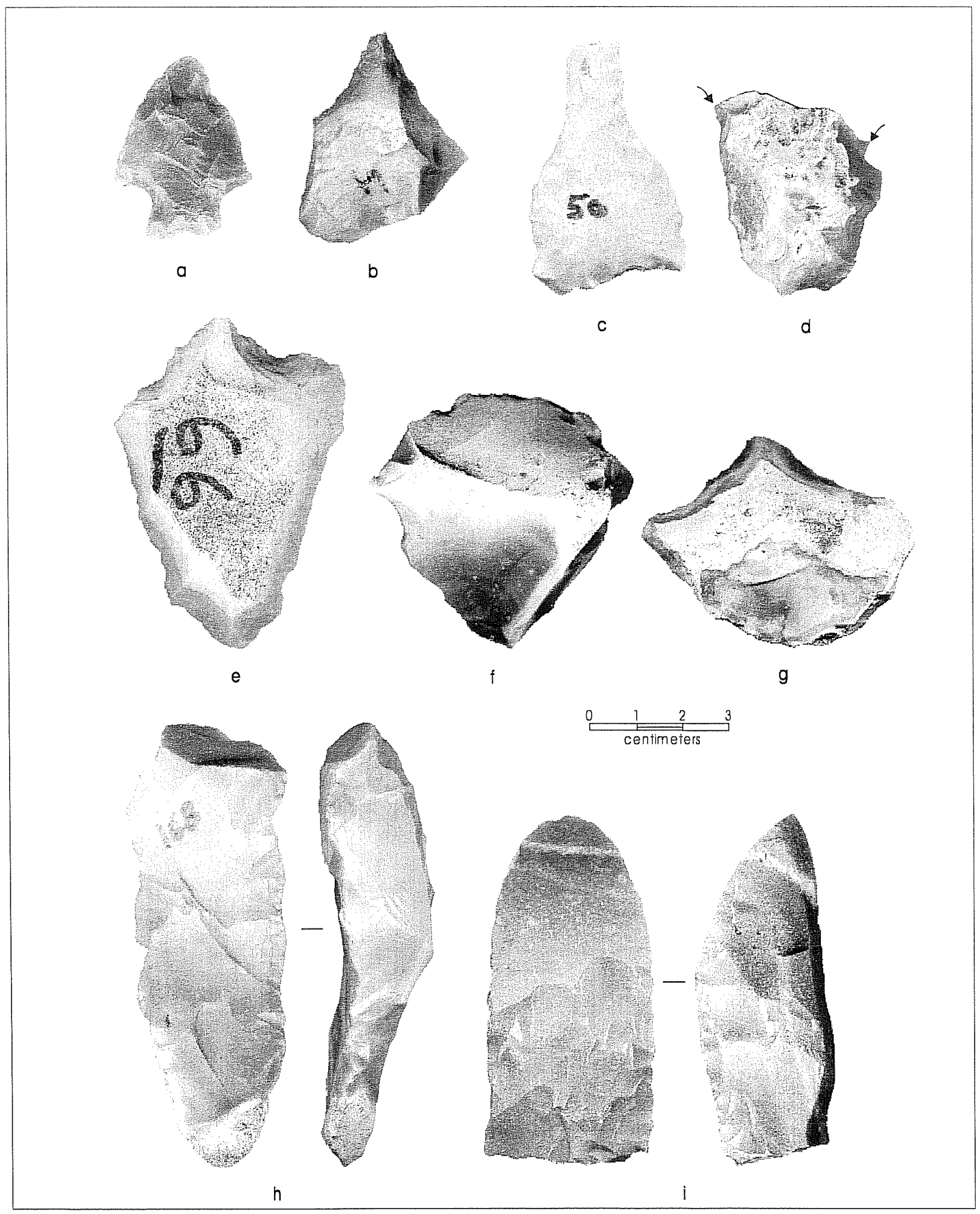

Figure 9. Artifacts recovered from 41BX1412: a) Uvalde dart point; b) reamer; c) drill from recycled dart point; d) expedient graver; e) minimally retouched graver; f) spurred graver; g) formal graver; $h$ ) complete Guadalupe adze; i) proximal Guadalupe adze fragment. 
been excavated from well-dated and undisturbed contexts, the available data from the Granberg II site (Hester and Kohnitz 1975; Hester 1979) and the Panther Springs Creek Site (Black and McGraw 1985:146) suggest that Guadalupe tools date to the later part of the Early Archaic, between approximately 3,600 and 3,400 B.C. (see also Turner and Hester 1993).

All of the specimens from 41BX1412 are surface finds. Only one (Specimen 168) is complete (Figure 9h). It has a working face (bit spine-plane, Brown 1985) angle of 64 degrees. The single proximal fragment recovered is more carefully flaked than the complete specimen but has an acute working face angle of 40 degrees (Figure 9i). While the first specimen fits well within the range of most Guadalupe tools, the working face angle of the proximal fragment appears to be very much at the lower extreme of the distribution (see Brown 1985).

The remaining three Guadalupe adzes are manufacture failed specimens. Two are complete and one is a distal specimen broken in manufacture along an imbedded fracture plane. All three have a tri-faceted cross-section and the flake-patterning characteristic of Guadalupe adzes, however, only one, the distal fragment, has the well-formed single-faceted bit characteristic of the type. In the case of the other two, the working face exhibits multiple flake removals that appear to have been designed to create a face angle that approximated that of a finished tool. If so, the final face angle and morphology would have been accomplished by the removal of a single large flake, consistent with Model No. 2 described by Black and McGraw (1985:Figure 31).

The sixth and final adze is a surface collected minimally retouched specimen. It is made on a short but wide single-faceted hard hammerstone flake. The intersection of the large single-faceted platform and the bulb of percussion form the rounded bit characteristic of Guadalupe adzes. A series of three short flakes were used to remove and round the otherwise sharp ridge created by the intersection of the bulbar surface and platform face. A single large flake removal, originating from the bulbar face, created the steep working face angle morphology (68 degrees) characteristic of the tool. The ventral face of the tool, that would otherwise be flaked, is a flat surface formed by an imbedded fracture plane. The bulb of percussion forms one of the lateral surfaces, while the corticate dorsal face of the parent flake forms the second lateral surface. The proximal end of the tool was broken in use, most likely in the process of prying and bending the tool towards the material being worked. Minimal retouch is present along one edge of the tool to shape the specimen for hafting. Use-wear, in the form of step fractured scars and polish, is present along the working edge. Localized patches of polish also are present on the ventral and bulbar face of the tool; this wear is the product of hafting.

\section{Scrapers and Scraper Planes}

One end scraper and two scraper planes are in the collection. Based on the degree of retouch employed in tool manufacture, the end scraper is a formal tool. A secondary hard hammerstone flake blank was used to make the tool. The distal working edge end is tangential to the longitudinal axis of the flake blank. Two primary macroflakes $(124 \times 97 \times 40 \mathrm{~mm}$ and $109 \times 58$ $x 49 \mathrm{~mm}$ ) have one and two unifacially retouched working edges, respectively. Irregularly spaced microflake scars are present on the ventral face of both tools along the unifacially retouched working edges. Some localized areas of polish also are notable on the ventral faces of these specimens immediately adjacent the working edges and on the protruding bulbs of percussion. The ventral face polish and micro-flaking indicate that these rather large tools were handheld scraper-planes most likely used in woodworking.

\section{Choppers/Wedges}

Twelve specimens have been identified as either choppers or wedges. All but one of these is a surface find. All artifacts have one or two bifacially flaked working edges and at least one of these edges is cortexbacked. All specimens are complete and range in weight from 146 to 1,072 grams with an average weight of 578.5 grams (s.d. $=295.7$ g). Assuming that an efficient chopper needs to be relatively heavy, while weight is less critical for a wedge, it is likely that at least the three lightest specimens $(146,313$, and 316 
grams, respectively) were used primarily as wedges. On the other hand, all other specimens may have been employed as both choppers and wedges. Use-wear, in the form of step fracturing, light edge-rounding, and localized polish on flake scar ridges and the working edges, is common on all but the three lightest specimens. No use-wear could be identified on these specimens at the low magnification range $(20-80 x)$ employed in this study. Of the eleven chopper/wedges, nine $(82 \%)$ have a single working edge, and two have two working edges.

\section{Miscellaneous Unifaces}

Three unifacially retouched flake fragments and a complete secondary flake are classified in this category. The fragmentary specimens lack use-wear and they are too small to determine blank and/or tool morphology. The large secondary flake $(66 \times 49 \times 16 \mathrm{~mm}$; Specimen 40) has one unifacially retouched corner and two isolated flake removals from the distal end. It appears to have been intended as an end scraper but was rejected prior to completion.

\section{Miscellaneous Bifaces}

A total of 61 bifacially flaked artifacts could not be classified into functional categories either because they do not exhibit use-wear, morphologically do not resemble existing tool forms, and/or have been broken prior to completion. Only six (10\%) of the specimens are from excavation. Of the 61 miscellaneous bifaces, $23(38 \%)$ are complete, $19(31 \%)$ are proximal, 7 $(11 \%)$ are distal, $6(10 \%)$ are edge or wedge segments, $5(8 \%)$ are medial, and 1 is a longitudinal fragment. Thirty-four $(89 \%)$ of the 38 incomplete specimens have been broken in manufacture. The cause-of-break could not be determined in the case of the additional four specimens. Based on stage of reduction, $39(64 \%)$ are early reduction specimens characterized by thick cross-sections, cortex on one or both faces, deep hard hammerstone flake scars, and sinuous bifacial edges. The remaining $22(36 \%)$ specimens are middle reduction stage bifaces characterized by somewhat thinner cross-sections, total lack of cortex, and more linear bifacial edges. Late reduction stage bifaces are entirely missing in the collection. The core/blank used in the manufacture of the bifaces could be determined for only 25 specimens. Flake cores are more common $(n=15,60 \%)$ than pebble cores. Two complete early reduction stage bifaces (Specimen 20 and 252) and an early reduction stage proximal fragment (Specimen 95) have overshot flake scars. Overshot flake removals are a systematically employed strategy in thinning Clovis blanks (see Collins 1999:46). However, the overshot flakes shown to the senior author by M. B. Collins clearly have been removed from middle to late reduction stage bifaces rather than the early stage specimens in this collection. However, the removal of overshot flakes earlier in the reduction may be even more effective in thinning the blanks and also may afford the opportunity to correct any manufacture problems derived from removal mistakes. An additional early reduction stage proximal biface fragment (Specimen 111) exhibits technological characteristics reminiscent of Clovis technology. This specimen was broken during the removal of a longitudinal base thinning flake. This base thinning strategy is commonly employed in thinning Clovis preforms and has been observed on a number of specimens from the Gault site (M. B. Collins, personal communication 1999; see also Callahan 1979).

\section{Cores}

Thirty-nine cores have been recovered from the site, all but one is a surface find. Unidirectional cores constitute the bulk of the specimens $(n=23,59 \%)$, followed by multidirectional $(n=10,26 \%)$ and bidirectional $(n=6,15 \%)$ specimens. The number of flake removals per core ranges from as few as one $(n=2)$ to as many as $23(n=1)$. The mean number of flake removals is 6.6 (s.d.=4.2) per core. If we consider that one to two flake removals may be necessary to assess the quality of the chert, it is likely that five specimens can be classified as tested cores. Judging from the average size of the cores, none of the specimens are exhausted. 
Table 5. Unmodified lithic debitage recovered from 41BX1412

\begin{tabular}{|c|c|c|c|c|c|c|c|c|}
\hline \multirow[b]{2}{*}{ Unit } & \multirow[b]{2}{*}{ Surface* } & \multicolumn{6}{|c|}{ Level } & \multirow[b]{2}{*}{ Grand Tota } \\
\hline & & 1 & 2 & 3 & 4 & 5 & 6 & \\
\hline 1 & 0 & 18 & 16 & 11 & 12 & 4 & 0 & 61 \\
\hline 2 & 12 & 40 & 26 & 50 & 61 & 12 & 28 & 229 \\
\hline ST 1 & 0 & 3 & 5 & 4 & 5 & 15 & 0 & 32 \\
\hline ST 2 & 0 & 0 & 1 & 0 & 0 & 0 & 0 & 1 \\
\hline ST 3 & 0 & 2 & 0 & 1 & 3 & 0 & 0 & 6 \\
\hline ST 4 & 0 & 0 & 1 & 0 & 0 & 0 & 0 & 1 \\
\hline ST 5 & 0 & 2 & 0 & 0 & 0 & 1 & 0 & 3 \\
\hline ST 6 & 0 & 1 & 3 & 1 & 1 & 0 & 0 & 6 \\
\hline ST 7 & 0 & 1 & 2 & 0 & 1 & 0 & 0 & 4 \\
\hline ST 8 & 0 & 1 & 1 & 1 & 3 & 1 & 0 & 7 \\
\hline ST 9 & 0 & 2 & 4 & 3 & 1 & 1 & 0 & 11 \\
\hline ST 10 & 0 & 9 & 3 & 0 & 2 & 0 & 0 & 14 \\
\hline ST 11 & 0 & 1 & 1 & 2 & 1 & 0 & 0 & 5 \\
\hline ST 12 & 0 & 2 & 5 & 3 & 2 & 2 & 0 & 14 \\
\hline ST 13 & 0 & 2 & 0 & 0 & 0 & 1 & 0 & 3 \\
\hline $\mathrm{ST} 14$ & 0 & 2 & 2 & 0 & 3 & 0 & 4 & 11 \\
\hline ST 15 & 2 & 2 & 2 & 2 & 0 & 0 & 0 & 8 \\
\hline ST 16 & 0 & 1 & 0 & 13 & 7 & 5 & 0 & 26 \\
\hline ST 17 & 0 & 3 & 0 & 4 & 1 & 0 & 0 & 8 \\
\hline ST 18 & 0 & 4 & 2 & 1 & 0 & 0 & 1 & 8 \\
\hline ST 19 & 0 & 4 & 0 & 0 & 0 & 0 & 0 & 4 \\
\hline ST 20 & 1 & 4 & 2 & 3 & 3 & 2 & 2 & 17 \\
\hline General Surface & 156 & 0 & 0 & 0 & 0 & 0 & 0 & 156 \\
\hline Grand Total & 171 & 104 & 76 & 99 & 106 & 44 & 35 & 635 \\
\hline
\end{tabular}

*surface at TU or ST.

\section{Unmodified Debitage}

A total of 635 unmodified lithic debitage was obtained from the site. The two TUs yielded 46 percent of the collection $(n=290), 30$ percent $(n=156)$ came from random surface collection, and 24 percent $(n=189)$ from STs. Table 5 shows the breakdown of unmodified debitage by recovery context. The horizontal distribution from the STs indicates that the subsurface densities tend to match the surface distribution of debitage (see STs 1, 10, 12, 16, and 20). That is, the northern end of the site, located adjacent to Bee Tree Drive, contains a heavier concentration of cultural materials than the southern half (see Figure 7).
Overall, the lithic debitage collection is dominated by tertiary specimens $(n=426,67 \%)$. However, the fact that about a third of the debitage is composed of secondary $(n=178,28 \%)$, and primary $(n=31,5 \%)$ specimens does indicate that the entire reduction sequence is represented in the sample. The high proportions of fragmentary debitage (proximal, $\mathrm{n}=141,22 \%$; medial, $\mathrm{n}=168,26 \%$; distal, $\mathrm{n}=137,22 \%$; longitudinal, $\mathrm{n}=1,<$ $1 \%$ ) may be due to a number of factors including, the fine-grained raw material, the predominance of relatively thin soft-hammer removals, and/or traffic following discard. A total of 297 (47\%) specimens are 
platform-bearing. Among these, single faceted striking platforms are the most common $(n=133,45 \%)$. The combined proportion of unprepared (i.e., corticate, $n=52,18 \%$ ) and minimally prepared (i.e., single faceted) platform-bearing flakes suggests that initial core reduction and/or early-stage biface manufacture may have been the predominant flintknapping activities carried out at the site. Finally, the analysis of debitage types in the collection indicates that a total of $197(31 \%)$ could not be categorized and $30(5 \%)$ are angular debris. Of the remaining 408 , the large majority $(n=286,70 \%)$ are core/platform preparation specimens. Debitage derived from bifacial reduction constitutes the second highest percentage $(n=96,23 \%)$, while unifacial reduction strategies and blade production contributed only small proportions.

The vertical distribution of debitage has a bimodal pattern (Table 5). Debitage frequencies decrease from surface through Level 2 and increase thereafter in Levels 3 and 4, only to decrease in the bottom two levels. This pattern is suggestive of two occupation or depositional zones in the site, one at or near the present surface and one between Levels 3 and 4 .

To investigate the possibility of multiple occupation zones within the site, we examined the patterning of mean debitage sizes by level within the collection obtained from the two TUs. Under normal depositional contexts, the smaller the surface area of a flake, the greater the likelihood that it will readily work its way down a profile. Inversely, the larger the surface area of the specimen, it is more likely that it will remain on or close to the original living surface, or it will have a slower movement rate. Given this general relationship, it is expected that the mean size of the debitage should decrease as one progresses below an original living and/or depositional surface.

The mean size of debitage obtained in the general surface collection is $62 \mathrm{~mm}$ (s.d. $=22.8$ ). In TU 1 the largest mean debitage size is found in Level 1 , and mean debitage size decreases with depth (see Levels 4 and 5; Table 6). In TU 2 the largest mean debitage size is found in the top two levels and mean debitage size decreases steadily in the next two levels. Significantly, however, mean debitage sizes increase again in Levels 5 and 6 to size ranges similar to those in the upper two levels. This pattern in debitage mean maximum dimension suggests the presence of two occupation/ depositional surfaces. It confirms the upper depositional surface at or near the present ground surface and indicates the presence of a second depositional surface either between $40-50$ or $50-60 \mathrm{~cm}$ bs.

During excavation and subsequent laboratory processing we observed that a proportion of the unmodified debitage was heavily patinated. The patina is of a white to light tan color. To test the existence of the deeper depositional surface by independent means, we decided to investigate the patterning in debitage patination by level within the two TUs. A total of 479 debitage pieces were recovered from the 20 STs and 2 TUs. The frequency of patination is relatively low among the debitage recovered from the surface of these units $(\mathrm{n}=15,27 \%)$ and from Levels $1(\mathrm{n}=104,17 \%)$ and $2(\mathrm{n}=76,36 \%)$. About half of the debitage from Levels 3-5 (Level 3, $n=99,52 \%$; Level 4, $n=106,53 \%$;

Table 6. Mean and standard deviation of debitage maximum dimension by level within the two TUs

\begin{tabular}{|l|c|c|c|c|c|c|}
\hline & \multicolumn{3}{|c|}{ Excavation Unit 1 } & \multicolumn{3}{c|}{ Excavation Unit 2 } \\
\cline { 2 - 7 } & Mean & S.D. & n & Mean & S.D. & n \\
\hline Level 1 & 26.30 & 13.30 & 18 & 21.50 & 10.50 & 40 \\
\hline Level 2 & 17.30 & 6.00 & 16 & 22.50 & 13.20 & 26 \\
\hline Level 3 & 17.40 & 4.90 & 11 & 17.10 & 5.70 & 50 \\
\hline Level 4 & 17.30 & 5.20 & 12 & 16.80 & 7.10 & 61 \\
\hline Level 5 & 17.00 & 3.90 & 4 & 20.40 & 10.00 & 12 \\
\hline Level 6 & & & & 22.20 & 9.50 & 28 \\
\hline
\end{tabular}


Level $5, \mathrm{n}=44,48 \%$ ) is patinated. In contrast, nearly $75 \%$ of the debitage from Level $6(n=35,74 \%)$ is patinated. Of the 35 patinated specimens from Level $6,28(80 \%)$ are from TU 2, indicating that the pattern is heavily skewed by this TU. Overall, the distribution of patinated debitage confirms the existence of a deep depositional zone in Level $6,50-60 \mathrm{~cm}$ bs. The presence of patinated debitage in the upper levels may be the result of bioturbation and/or the upward movement of materials due to argilliturbation processes within clay soils (Waters 1992:299-300).

A total of 203 patinated and 276 unpatinated pieces of debitage were recovered from the 20 STs and 2 TUs. The comparison of debitage attributes within the patinated and unpatinated subgroups identifies a few notable differences. In terms of debitage completeness, the principal difference between the two subsets lies in the higher proportion of angular debris within the unpatinated $(\mathrm{n}=21,8 \%)$ versus the patinated specimens $(n=8,4 \%)$. This difference may reflect the predominance of hard hammerstone flake removals in the unpatinated debitage versus the use of soft hammer billet flaking in the patinated debitage collection. This pattern, may in turn, indicate higher proportions of late reduction stage removals in the patinated collection. These conclusions are supported by platform faceting trends. While 57 percent $(n=48)$ of the patinated platform-bearing flakes have two or more platform facets, only 39 percent of the unpatinated platform-bearing flakes have two or more platform facets. A similar conclusion can be drawn from the cortex category data. While 85 percent $(n=173)$ of the patinated debitage is tertiary, only 73 percent $(n=200)$ of the unpatinated debitage collection is entirely decorticate. In terms of flake type patterning, the main difference between the two subgroups is in the slightly higher percentage of bifacial reduction debitage (e.g., manufacture, thinning, rejuvenation) in the patinated debitage collection ( $n=36,26 \%)$ compared to the unpatinated debitage $(n=39,22 \%)$.

Overall then, the combination of the mean debitage size patterning by depth, the percentage of patinated debitage by level, and subtle but important technological differences between the patinated and unpatinated debitage collections all suggest that two possible depositional surfaces or cultural zones are present at the site. One depositional surface appears to have been on or near the present ground surface, and the other may be buried in Level 4 or deeper.

No doubt, some vertical mixing of materials from these different zones has occurred due to bioturbation and argilliturbation. However, the identification and assignment of individual artifacts to the appropriate zone should be enhanced by the presence of heavy patina on the artifacts from the deeper zone and unpatinated character of the artifacts from the overlying zone. A good example of this potential is the perforator made on a recycled dart point found on the surface. In addition to its morphological and technological traits reminiscent of Paleoindian lanceolate dart points, the drill is also heavily patinated. On the other hand, the majority of the other temporal diagnostic artifacts recovered from the site (i.e., Uvalde dart point, Guadalupe adzes) are not patinated and are tentatively dated to the Early Archaic. This example illustrates how bioturbation and argilliturbation should not hinder the careful study and analysis of the two lithic assemblages associated with the two depositional surfaces.

\section{Fire Cracked Rocks and Heat Spalls}

Although no features have been identified in the STs and TUs, scattered fragments of burned rock and numerous heat spalls were recovered. Most of the fire cracked rock (FCR) noted on the surface and recovered from excavation was two inches in diameter or smaller. The tabulation of FCR and heat spalls by level from STs and TUs indicates that Levels $1-3$ have the highest frequencies (Level 1, $\mathrm{n}=51$; Level 2, $\mathrm{n}=26$; Level 3, $\mathrm{n}=36$ ). Their frequencies decrease significantly in the bottom three levels (Level 4, $n=21$; Level $5, \mathrm{n}=10$; Level $6, \mathrm{n}=7$ ). These patterns indicate that thermal facilities employing heated rocks are likely to be present on-site and they may be concentrated in the upper $30 \mathrm{~cm}$ of the deposits. Given the lack of visible soil disturbances, corroborated in part by $\mathrm{Mr}$. Klar's statements, it is possible that shallowly buried intact features may be located between Bee Tree Drive and TUs 1 and 2. 


\section{The 41BX1412 Assemblage in the Broader Early Archaic Context}

\author{
Steve A. Tomka
}

The number of temporal diagnostic artifacts recovered from 41BX1412 is relatively low in view of the quantity of lithic artifacts noted on surface and recovered from excavation. Furthermore, it is notable that non-projectile point temporal diagnostics are more common than projectile points from the site. It is likely that surface collection of recognizable artifacts by park visitors has decreased the number of projectile points recovered during this project. It is possible that this type of random surface collection of projectile points could have obliterated the evidence for multiple Prehistoric components from the site.

Although some indicators of multi-componency may have been removed, the non-projectile point artifacts recovered from the site form a relatively coherent assemblage oriented to wood (i.e., Guadalupe adzes, cobble tools, scraper planes) and/or bone working (i.e., gravers, reamers). In addition, the abundance of early reduction stage bifaces and cores indicates some emphasis on tool manufacture, including the making of bifacial cutting tools and/or projectile points. Finally, the technological features of the assemblage are also coherent and reflect no characteristics that can be linked with Late Archaic and/or Late Prehistoric assemblages (e.g., absence of formal end scrapers, bladelets, arrow points).

Recent summaries of regional archaeology (Collins 1995; Hester 1995; Johnson and Goode 1994) disagree somewhat about the beginning and end of the Early Archaic in Central Texas and along the southern edge of the Edwards Escarpment. In general, however, the Early Archaic is thought to extend from 6,500-3,500 B.C. (Johnson and Goode 1994; although see Hester 1995). Only a few radiocarbon assays of wood charcoal from undisturbed contexts are available, including Arenosa Shelter (3435 \pm 130 B.C., Valastro and Davis 1970:636), Devil's Mouth Site (3635 \pm 175 B.C., Valastro et al. 1967:445), Eagle Cave (4945 \pm 220 B.C., Pearson et al. 1965), Devil's Rockshelter $(6300 \pm 300$ B.C., Valastro et al. 1967:445), Camp Pearl Wheat $(5300 \pm 190$ B.C., humate radiocarbon date; Collins et al. 1990:84) and the Wilson-Leonard Site (6700-4000 B.C., Collins 1998:282). Prewitt $(1981,1983)$ includes four phases (Circleville, San Geronimo, Jarrell, and Oakalla) in the Early Archaic, each with its own set of index-marker projectile point types. Some archaeologists consider the Angostura, Golandrina, Meserve, and Scottsbluff (Collins 1995; Prewitt 1981) point types as part of the Early Archaic period. These lanceolate projectile points not withstanding, in general two horizons (Early Corner Notched and Early Basal Notched; Hester 1995) and/ or projectile point series (Early Barbed and Early SplitStem; Johnson and Goode 1994) are included in the Early Archaic. While there are some disagreements as to which point types fall within these horizons/series, Early Archaic Central Texas point types include Gower, Hoxie, Jetta, Martindale, Uvalde, Baker, Bandy, Andice, and Bell.

A number of Early Archaic sites and/or components exist along the eastern edge of the Edwards Escarpment, in geographical and geomorphic settings similar to 41BX1412. Some of the more notable sites with Early Archaic components are the Landslide site (41BL85, Sorrow et al. 1967), the Sleeper site (41BC65, Johnson 1991), the La Jita site (41UV21, Hester 1971), the Panther Springs Creek site (41BX228, Black and McGraw 1985; Potter et al. 1995), the Camp Pearl Wheat site (41KR243, Collins et al. 1990), the Jetta Court site (41TV51, Wesolowsky et al. 1976), the Devil's Rockshelter (41VV264, Prewitt 1966), the Devil's Mouth site (41VV88, Johnson 1964), Baker Cave (41VV213, Chadderdon 1983; Word and Douglas 1970), and Arenosa Shelter (41VV99, Collins 1974). The predominance of Early Archaic components along the eastern and southeastern margins of the Edwards Plateau and in the Lower Pecos is suggestive of a "culture area" (Johnson 1991:149) characterized by broad similarities in adaptation and material culture.

Although a number of Early Archaic components are known from within the broader region (see also Collins 1995), nearly all of them contain mixed deposits and temporal diagnostics from a number of phases assigned to the period. The Sleeper site (Johnson 1991) is the only site with a lithic assemblage dominated by "Early Split Stem" points (i.e., Uvalde, Uvalde-like; n=13). 
Six other points from the site range from Paleoindian to late Early Archaic types including an untyped Paleoindian point, a Bell/CalfCreek, and a Martindale. The Sleeper site assemblage does have some similarities to the 41BX1412 assemblage, specifically in terms of the scarcity of scrapers and knives, and the predominance of wood working tools. The wood working emphasis of the lithic assemblage is also seen in the Early Archaic assemblage from the Panther Springs Creek site (Black and McGraw 1985).

The 41BX1412 assemblage is, however, unique even in light of the Sleeper site collection. The recovery of a single point type (i.e., Uvalde) is potentially indicative of an Early Archaic component occupied during the later part of the Early Archaic. The recovery of multiple Guadalupe adzes, also thought to date to the later part of the Early Archaic (see adze discussion), supports the Uvalde association. More importantly, the 41BX1412 occupation may represent the first instance in which Guadalupe adzes and Uvalde points may be associated as part of a functional tool kit.

In addition to the late Early Archaic component, technological aspects of the lithic debitage, as well as a drill made on a recycled dart point, suggest the existence of a deeper Paleoindian component at the site. Based on differential patination and stratigraphic position, it is likely that the two components can be isolated and differentiated for analytical purposes.

\section{Summary and Recommendations}

\author{
Steve A. Tomka
}

Between September 16 and October 21, 1999, CAR personnel conducted an intensive pedestrian survey and subsurface testing for potential cultural deposits along the proposed roadway extension through McAllister Park. The proposed extension impacts two sections of the McAllister Park road system: the extreme western portion adjacent the park-entrance at Jones Maltsberger Road, and its southern section at Starcrest Drive.

Three sites were identified and documented during this pedestrian survey. Site $41 B X 1410$ is located approximately $200 \mathrm{~m}$ east of the park's entrance at Jones Maltsberger. It covers approximately $162 \mathrm{~m}^{2}$. Three STs were excavated in the site. Two reached a depth of $10 \mathrm{~cm} \mathrm{bs}$, the third penetrated to $15 \mathrm{~cm}$ bs before reaching limestone. Four tertiary flakes and seven modern glass fragments, were recovered from ST 1 , Level $1(0-10 \mathrm{~cm}$ bs). The low density lithic scatter, and shallowness of the deposits indicate an ephemeral occupation. The site is not warranted for State Archeological Landmark (SAL) designation, and no further work is recommended at this site.

Site 41BX1411 is located approximately $75 \mathrm{~m}$ east of 41BX1410. It covers about $130 \mathrm{~m}^{2}$. A light scatter of flakes, cores, and an early reduction stage biface were observed on the surface. Three STs were excavated to a depth of $20 \mathrm{~cm}$ bs. A total of four tertiary flakes were recovered (ST 1, Level 2, $\mathrm{n}=1$; ST 2, Level 2, $\mathrm{n}=1$; and ST 3, Level, $1 \mathrm{n}=2$ ). Given the low material recovery and shallowness of the site, we suggest that the site is not warranted for SAL designation, and no further work is recommended at this site.

Site 41BX1412 is a multi-component site (Historic/ Prehistoric) located on an upland terrace on the south bank of Mud Creek. It is bisected by a sharp turn in Bee Tree Drive. The majority of the surface cultural materials consist of Prehistoric chipped lithics although a light veneer of Historic materials is also scattered across the site. The Historic materials date from the late nineteenth and early twentieth century. The densest Prehistoric artifact scatter is south of Bee Tree 
Drive within a lightly wooded area. Material densities drop rapidly southward as one approaches a barbed wire fence at the southern boundary of the site. A total of 20 STs and two $1 \times 1$ meter TUs were dug. A surface collection of artifacts also was carried out on site. The shovel tests reached to a depth of between 40 and $60 \mathrm{~cm}$ bs. The two TUs were dug to $60 \mathrm{~cm}$ bs. The analysis of the 779 Prehistoric artifacts recovered from the site indicates the presence of two potentially isolable components:

1) An Early Archaic component dating from the end of the period; and

2) A probable Paleoindian component of unknown age.

Although some degree of mixing of materials from the two components has occurred, the differential patination of artifacts from the two components should allow their clear separation.

Based on the findings of the limited testing conducted at $41 \mathrm{BX} 1412$, the site can make three significant contributions to regional archaeology:

1) The potential to document an isolable Uvalde component dating to the later part of the Early Archaic;

2) The potential to establish solid behavioral association between Uvalde dart points and Guadalupe adzes; and

3) The possibility to identify and document an isolable Paleoindian component of hitherto unknown age.

Given the significant research contribution each of these themes can make to regional archaeology, the site is recommended for designation as a State Archeological Landmark and for nomination to the National Register of Historic Places (NRHP).

In light of the fact that the proposed road extension cannot be relocated, we recommend that data recovery excavations be carried out at 41BX1412 to mitigate the impact of site disturbances expected to occur during road construction activities. Previous construction of Bee Tree Drive has negatively impacted a portion of the site measuring approximately $1,500 \mathrm{~m}^{2}(50$ $x 30$ meters). The site area bounded within the current ROW measures approximately $2,100 \mathrm{~m}^{2}(70 \times 30$ meters). Overall then, previous and proposed construction activities will have negatively impacted a total of $3,600 \mathrm{~m}^{2}$, or approximately 72 percent of the site (site size $=5,000 \mathrm{~m}^{2}$ ). Artifactually, both in terms of surface and subsurface manifestations, the densest portion is found in the center of the site. This area measures approximately $360 \mathrm{~m}^{2}(13 \times 20$ meters $)$. The two $1 \times 1$ meter test units previously excavated in the site were placed in this area. The two proposed $2 \times 2$ meter blocks would mitigate an additional 2.2 percentage of this area.

It is impossible to determine the nature of the deposits impacted by the construction of Bee Tree Drive. However, given that both surface and subsurface materials tend to become more dense as one approaches Mud Creek, it is likely that a dense occupation area was impacted by the previous construction. As indicated by the present ROW boundary, the proposed construction would also cut through the densest portion of the site as documented by both surface distribution of artifacts and subsurface testing.

Data recovery should focus on the following goals:

1) Recover a larger and more representative sample of the late Early Archaic lithic assemblage;

2) Define and more extensively sample the probable Paleoindian component found in the two deepest levels of the site;

3) Locate and excavate features from both components; and

4) Recover datable organic materials from the two components.

To accomplish the first two goals it is recommended that two $2 \times 2$ meter blocks be excavated in the central portion of the site adjoining TUs 1 and 2 . It is estimated, based on artifact yields from TUs 1 and 2, 
that the block excavation units may yield a total of 1,352 chipped lithic artifacts. Again, based on previous results, it is estimated that approximately 487 (36 $\%$ ) of these may derive from Levels 4 through 6 , and may be representative of the possible late Paleoindian component.

To locate features representative of either component, up to 20 shovel tests will be excavated between Bee Tree Drive and the tree line (Figure 7). In the event that these shovel tests uncover no evidence of features, further excavations will not be conducted. Should these shovel tests identify intact features, these will be excavated using additional hand-excavated 1 $x 1$ meter units. Datable materials (i.e., charcoal) recovered from primary contexts, either associated with these features or from clearly identifiable stratigraphic units, will be submitted for ${ }^{14} \mathrm{C}$ dating.

Artifacts recovered from the block excavations, isolated $1 \times 1$ meter units, and shovel tests will be processed at the CAR laboratory. They will be analyzed to define their technological affiliation as well as their depositional history (e.g., size distribution by depth, proportion of patinated debitage by level). A report detailing the results of these investigations will be issued by the Center for Archaeological Research. 


\section{References Cited}

Black, S. L., and A. J. McGraw

1985 The Panther Springs Creek Site: Culture Change and Continuity within the Upper Salado Creek Drainage, South Central Texas. Archaeological Survey Report, No. 100. Center for Archaeological Research, The University of Texas at San Antonio.

Blair, W. F.

1950 The Biotic Provinces of Texas. Texas Journal of Science 2(1):93-117.

Boldurian, A. T.

1990 Lithic Technology at the Mitchell Locality of Blackwater Draw: A Stratified Folsom Site in Eastern New Mexico. Plains Anthropologist, Memoir 24, 35(130):1-115.

Brown, K. M.

1985 Three Caches of Guadalupe Tools from South Texas. Bulletin of the Texas Archeological Society 56:75-126.

Callahan, E.

1979 The Basics of Biface Knapping in the Eastern Fluted Point Tradition: A Manual for Flintknappers and Lithic Analysts. Archaeology of Eastern North America 7(1):1-180.

Chadderdon, M. F.

1983 Baker Cave, Val Verde County, Texas: The 1976 Excavations. Special Report 13. Center for Archaeological Research, The University of Texas at San Antonio.

Collins, M. B.

1974 A Functional Analysis of Lithic Technology among Prehistoric Hunter-Gatherers of Southwestern France and Western Texas. Unpublished Ph.D. dissertation, Department of Anthropology, University of Arizona, Tucson.

1995 Forty Years of Archeology in Central Texas. Bulletin of the Texas Archeological Society 66:361-400.

1999 Clovis Blade Technology A Comparative Study of the Keven Davis Cache, Texas. University of Texas Press, Austin.

Collins, M. B. (editor)

1998 Wilson-Leonard An 11,000-year Archeological Record of Hunter-Gatherers in Central Texas. Volume I: Introduction, Background, and Syntheses. Studies in Archeology 31. Texas Archeological Research Laboratory. The University of Texas at Austin. Archeological Studies Program, Report 10. Texas Department of Transportation. Environmental Affairs Department, Austin.

Collins, M. B., B. Ellis, and C. Dodt-Ellis

1990 Excavations at the Camp Pearl Wheat Site (41KR243) An Early Archaic Campsite on Town Creek Kerr County, Texas. Studies in Archeology 6. Texas Archeological Research Laboratory, The University of Texas at Austin. 
Fox, A. A.

1973 An Archeological Survey of the Northeast Preserve and J Street Park San Antonio, Texas. Technical Bulletin No. 2. Texas Archeological Research Laboratory, University of Texas at Austin.

1977 An Archaeological Assessment of the San Antonio 201 Wastewater Project. Archaeological Survey Report, No. 41. Center for Archaeological Research, The University of Texas at San Antonio.

1998 Stoneware Potteries in the San Antonio Area. Presentation at "From the Land-19 $9^{\text {th }}$ Century Texas Stoneware Seminar." National Wildflower Research Center, Austin.

Hester, T. R.

1971 Archeological Investigations at the La Jita Site, Uvalde County, Texas. Bulletin of the Texas Archeological Society 42:51-148.

1979 Early Populations in Prehistoric Texas. Archaeology 32(6):26-33.

1989 Introduction. In From the Gulf Coast to the Rio Grande: Human Adaptation in Central, South, and Lower Pecos Texas, by T. R. Hester, S. L. Black, W. Olive, A. A. Fox, K. Reinhart, and L. C. Bement, pp. 39-62. Research Series No. 33. Arkansas Archeological Survey, Fayetteville.

1995 The Prehistory of South Texas. Bulletin of the Texas Archeological Society 66:427-460.

Hester, T. R., and H. Kohnitz

1975 Chronological Placement of "Guadalupe" Tools. La Tierra 2(2): 22-25.

Howard, C. D.

1990 The Clovis Point: Characteristics and Type Description. Plains Anthropologist 35(129):255-262.

Johnson, L., Jr.

1964 The Devil's Mouth Site, A Stratified Campsite at Amistad Reservoir, Val Verde County, Texas. Archaeology Series 6. Department of Anthropology, The University of Texas at Austin.

1986 A Plague of Phases: Recent Sociocultural Taxonomy in Texas Archeology. Bulletin of the Texas Archeological Society 57:1-26.

1991 Early Archaic Life at the Sleeper Archaeological Site, 41BC65 of the Texas Hill Country Blanco County, Texas. Publications in Archeology, Report No. 39. Texas State Department of Highways and Public Transportation, Austin.

Johnson, L., Jr., and G. T. Goode

1994 A New Try at Dating and Characterizing Holocene Climates, as well as Archeological Periods, on the Eastern Edwards Plateau. Bulletin of the Texas Archeological Society 65:1-51.

Katz, P. R.

1987 Archaeological Mitigation at 41BX300, Salado Creek Watershed, South-Central Texas. Archaeological Survey Report, No. 130. Center for Archaeological Research, The University of Texas at San Antonio.

Kibler, K. W., K. E. Stork, and L. W. Klement

1998 Archeological Survey at Camp Stanley Storage Activity, Bexar County, Texas. Reports of Investigations No. 108. Prewitt and Associates, Inc., Austin.

LBJ School of Public Affairs

1978 Preserving Texas 'Natural Heritage. LBJ School of Public Affairs, Report 31. Austin. 
Miller, G. L., and C. Sullivan

1984 Machine-made Glass Containers and the End of Production for Mouth-Blown Bottles. Historical Archaeology 18(2):81-96.

Pearson, F. J., Jr., E. M. Davis, M. A. Tamers, and R. W. Johnstone

1965 University of Texas Radiocarbon Dates III. Radiocarbon 7:296-314.

Potter, D. R., S. L. Black and K. Jolly

1995 Archeology Along the Wurzbach Parkway Module I Introduction, Conceptual Framework, and Contexts of Archeological Investigations in Bexar County, South-Central Texas. Studies in Archeology 17. Texas Archeological Research Laboratory, The University of Texas at Austin.

Prewitt, E. R.

1966 A Preliminary Report on the Devil's Rockshelter Site, Val Verde County, Texas. Texas Journal of Science 19(2):206-224.

1981 Cultural Chronology in Central Texas. Bulletin of the Texas Archeological Society 52:65-89.

1983 From Circleville to Toyah: Comments on Central Texas Chronology. Bulletin of the Texas Archeological Society 54:201-238.

Riskind, D. H., and D. D. Diamond

1986 Plant Communities of the Edwards Plateau of Texas: An Overview Emphasizing the Balcones Escarpment Zone Between San Antonio and Austin with Special Attention to Landscape Contrasts and Natural Diversity. In The Balcones Escarpment: Geology, Hydrology, Ecology and Central Texas, edited by P. L. Abbott and C. M. Woodruff, pp. 21-32. Comment Reproduction Service, Santa Fe Springs.

Scott, A. M., K. W. Kibler, M. D. Freeman, and S. P. Austin

1998 Archeological Survey and Testing at Camp Stanley Activity, Bexar County, Texas. Reports of Investigations No. 115. Prewitt and Associates, Inc., Austin.

Sorrow, W. M., H. J. Shafer, and R. E. Ross

1967 Excavations at Stillhouse Hollow Reservoir. Miscellaneous Papers No. 11. Texas Archeological Salvage Project, The University of Texas at Austin.

Taylor, F. B., R. B. Hailey, and D. L. Richmond

1962 Soil Survey of Bexar County, Texas. United States Department of Agriculture, Soil Conservation Service.

Tomka, S. A., and A. A. Fox

1999a Archaeological Investigations of Rainwater Catchment Basins along the South Wall of Mission San José, San Antonio, Texas. Archaeological Survey Report, No. 287. Center for Archaeological Research, The University of Texas at San Antonio.

1999b Mission San José Repointing and Underpinning Project, San Antonio, Texas. Archaeological Survey Report, No. 294. Center for Archaeological Research, The University of Texas at San Antonio.

Turner, S. E., and T. R. Hester

1993 A Field Guide to Stone Artifacts of Texas Indians. Second Edition. Texas Monthly Field Guide Series. Gulf Publishing Company, Houston. 
Valastro, S., Jr., and E. M. Davis

1970 University of Texas at Austin Radiocarbon Dates VIII. Radiocarbon 12(2):617-639.

Valastro, S., Jr., F. J. Pearson, Jr., and E. M. Davis

1967 University of Texas at Austin Radiocarbon Dates V. Radiocarbon 9:439-453.

Waters, M. R.

1992 Principles of Geoarchaeology, A North American Perspective. The University of Arizona Press, Tucson.

Wesolowsky, A. B., T. R. Hester, and D. R. Brown

1976 Archeological Investigations at the Jetta Court Site (41TV151) Travis County, Texas. Bulletin of the Texas Archeological Society 47:25-87.

Word, J. H., and C. L. Douglas

1970 Excavations at Baker Cave, Val Verde County, Texas. Bulletin 16. Texas Memorial Museum, The University of Texas at Austin. 

Appendix 1 
Appendix 1.1.

Dart Point and Perforators from 41BX1412

\begin{tabular}{|c|c|c|c|c|c|c|c|c|c|c|c|c|}
\hline \multicolumn{2}{|c|}{ Level L } & Type & $\begin{array}{c}\text { Max. Length } \\
(\mathrm{mm})\end{array}$ & Max. Width & Max. Thickness & $\begin{array}{l}\text { Blade } \\
\text { Width }\end{array}$ & $\begin{array}{l}\text { Neck } \\
\text { Width }\end{array}$ & Stem Width & $\begin{array}{l}\text { Base } \\
\text { Width }\end{array}$ & $\begin{array}{l}\text { Stem } \\
\text { Length }\end{array}$ & $\begin{array}{l}\text { Blade } \\
\text { Length }\end{array}$ & \\
\hline \multirow{2}{*}{\multicolumn{13}{|c|}{ one missing ear; impact broken tip w, reworkinq }} \\
\hline & & & & & & & & & & & & \\
\hline \multirow[t]{3}{*}{ Unit } & Level & $\begin{array}{c}\text { Specimen } \\
\text { Number }\end{array}$ & Blank Type & $\begin{array}{c}\text { Perforator } \\
\text { Type } \\
\end{array}$ & Completeness & Length & Width & Thickness & & & & Comments \\
\hline & surface & 79 & secondary flk & reamer & complete & 51 & 42 & 18 & made or & thick hh & lake: not 1 & gatinated; minimally retouched blade edges \\
\hline & surface & 4 & tertiary flake & reamer & complete & 49 & 35 & 19 & thick hh & flake: not & gatinated: & min. retouched blade; heavy polish on ventral face \\
\hline \multirow[t]{2}{*}{ ST 3} & 2 & & tertiary flake & reamer & proximal frag. & $49^{*}$ & 34 & 16 & on reck & led mode & atelv patir & nated flake: tip broken; diff. patina very notable \\
\hline & surface & 50 & projectile point & drill & proximal frag. & $53^{*}$ & 34 & 9 & made or & lanceola & e dart poil & nt: heavy patina on both faces; Paleoindian flaking \\
\hline
\end{tabular}


Appendix 1.2.

Engravers from 41BX1412

\begin{tabular}{|c|c|c|c|c|c|c|c|c|c|c|c|}
\hline Unit & Level & $\begin{array}{c}\text { Specimen } \\
\text { Number }\end{array}$ & Blank Type & $\begin{array}{c}\text { Manyfacture } \\
\text { Type }\end{array}$ & $\begin{array}{c}\text { No. of } \\
\text { Working } \\
\text { Edges }\end{array}$ & Completeness & $\begin{array}{l}\text { No. of } \\
\text { Burin } \\
\text { Scars }\end{array}$ & Length & Width & Thickness & Comments \\
\hline EU 1 & 5 & & tert. fik. frag & Expedient & 1 & complete & 2 & 18 & 13 & 5.5 & Datinated both faces \\
\hline \multirow{5}{*}{ EU 1} & 4 & & tert. flake & expedient & 1 & complete & 1 & 26 & 14 & 5.5 & Iongitudinally solit flake; patinated both faces \\
\hline & surface & 139 & secondary flk & formal & 2 & one tip broken & 0 & 60 & 45 & 16 & not patinated: the two tios formed by adjacent retouch \\
\hline & surface & 217 & secondary flk & minimally ret & 1 & complete & 0 & 53 & 38 & 17 & hot patinated; one edqe retouched other unretouched \\
\hline & surface & 208 & secondary flk & Expedient & 3 & complete & $3 \& 4$ & 45 & 37 & 13 & proximal flake fraq with use on both break-face corners \\
\hline & surface & 172 & tertiary flk & minimally ret & 1 & tip broken & 0 & 55. & 34 & 10 & made by retocuheing a concave area adjacent corner of flake \\
\hline \multirow[t]{4}{*}{ EU1 } & 1 & & secondary fik & expedient & 1 & complete & 1 & 37 & 42 & 17 & employs a corner of platiorm, micro flakes derived from use \\
\hline & surface & 249 & secondary fik & minimally ret & 1 & complete & 0 & 55 & 59 & 24 & spurred graver type sim. to spurred end scrapers, not patinated \\
\hline & surface & 38 & secondary fik & minimally ret & 2 & complete & 1 & 72 & 52 & 18 & two graver tips with wear and one poss. burin scar. \\
\hline & surface & 128 & secondary flk & minimally ret & 2 & tips broken & 0 & 61 & 47 & 18 & not patinated; both tips broken possibly in use or resharpening \\
\hline \multirow[t]{4}{*}{ EU2 } & 4 & & tertiary flk & minimally ret & 1 & complete & 0 & 37 & 27 & 9 & not patinated, blank is a unifacial tool manufacture/resharp. flake \\
\hline & suriace & 66 & secondary flk & minimally ret & 2 & one tip broken & 0 & 71 & 49 & 18 & not patinated; graver tips formed by deep notch on end of flake \\
\hline & surface & 173 & secondary fik & minimally ret & 2 & complete & 0 & 70 & 48 & 17 & not patinated; graver tips formed by deep notch on end of flake \\
\hline & surface & 28 & tertiary fik & minimally ret & 1 & complete & 3 & 95 & 59 & 17 & not patinated; small corner with use scars and burin scars \\
\hline
\end{tabular}


Appendix 1.3.

Adzes from 41BX1412

\begin{tabular}{|c|c|c|c|c|c|c|c|c|c|}
\hline Level & $\begin{array}{c}\text { Specimen } \\
\text { Number }\end{array}$ & $\begin{array}{c}\text { Manufacture } \\
\text { Type } \\
\end{array}$ & Adze Type & $\begin{array}{l}\text { Edge } \\
\text { Angle } \\
\end{array}$ & Completeness & Length & Width & Thickness & Comments \\
\hline surface & & formal & Guadalupe & 40 & distal end & $73^{*}$ & 36 & 27 & well made, no indication of direction of blow for working face \\
\hline surface & 168 & formal & Guadalupe & 64 & complete & 98 & 34 & 24 & crude but finished; flake scar on working face indicating removal direction \\
\hline surface & 104 & formal & Guadalupe & 70 & distal frag & $40^{*}$ & 48 & 32 & manufacture failed distal frag; imbedded fracture line; face not well defined \\
\hline surface & 180 & formal & Guadalupe & none & complete & 92 & 38 & 37 & manuf. reject; compl. but never acquired correct form/working face morph. \\
\hline surface & & formal & Guadalupe & 70 & complete & 97 & 52 & 37 & may be manuf. failure or heavily rejuvenated adze; will check for use-wear \\
\hline surface & 108 & expedient & Expedient & 68 & distal & 75 & 55 & 33 & expedient adze made on large secondary flake; $w$. micro-wear \\
\hline
\end{tabular}


Appendix 1.4.

Scrapers and scraper planes from 41BX1412

\begin{tabular}{|c|c|c|c|c|c|c|c|c|}
\hline Level & $\begin{array}{c}\text { Specimen } \\
\text { Number }\end{array}$ & Blank Type & Uniface Type & Completeness & Length & Width & Thickness & \\
\hline surf. & 163 & secondary flk & comb. end/side scraper & complete & 63 & 49 & 17 & not patinated: secondarv flake w. two modified and used edges \\
\hline surf. & 149 & primary macro flk & scraper plane & complete & 124 & 97 & 40 & large hh flake with two retouched and used edges \\
\hline surf. & 187 & primary macro flk & scraper plane & complete & 109 & 58 & 49 & large hh flake with one modified edqe; lateral marain \\
\hline
\end{tabular}


Appendix 1.5.

Choppers/Wedges from 41BX1412

\begin{tabular}{|c|c|c|c|c|c|c|c|c|c|}
\hline Unit & Level & $\begin{array}{l}\text { Specimen } \\
\text { Number }\end{array}$ & Complete & $\begin{array}{l}\text { Maximum } \\
\text { Length }\end{array}$ & $\begin{array}{l}\text { Maximum } \\
\text { Width }\end{array}$ & $\begin{array}{l}\text { Maximum } \\
\text { Thickness }\end{array}$ & $\begin{array}{l}\text { Use } \\
\text { Wear }\end{array}$ & Weight & Comments \\
\hline & surface & 7 & Complete & 136 & 106 & 85 & present & 1072 & cortex backed, single bifacial edge \\
\hline & surface & 60 & Complete & 122 & 86 & 76 & present & 731 & cortex backed, single bifacial edge \\
\hline & surface & 94 & Complete & 158 & 102 & 59 & present & 1011 & cortex backed, single bifacial edqe \\
\hline & surface & 126 & Complete & 88 & 118 & 52 & present & 577. & cortex backed, single bifacial edqe \\
\hline & suriace & Ui 3 & Complete & 85 & 82 & 44 & absent & 313 & cortex backed, single bifacial edqe; may be blank \\
\hline & surface & 214 & Complete & 132 & 88 & 80 & present & 855 & cortex backed, two bifacial edges \\
\hline & surface & 310 & Complete & 74 & 120 & 56 & present & 444 & one working edge cortex backed, second edge not backed \\
\hline & surface & 251 & Complete & 92 & 78 & 52 & absent & 339 & contex backed, one bifacial edge \\
\hline & surface & 14 & Complete & 153 & 102 & 35 & present & 690 & cortex backed, one bifacial edge \\
\hline & surface & 88 & Complete & 114 & 73 & 35 & absent & 316 & cortex backed, one bifacial edqe \\
\hline & surface & 184 & Complete & 71 & 59 & 33 & absent & 146 & Gortex backed, two bifacial edges \\
\hline ST 12 & 1 & & Complete & 109 & 87 & 54 & minimal & 448 & cortex backed, one bilacial edqe \\
\hline
\end{tabular}


Appendix 1.6.

Miscellaneous bifaces from 41BX1412

\begin{tabular}{|c|c|c|c|c|c|c|c|c|c|c|}
\hline Unit & Level & $\begin{array}{l}\text { Specimen } \\
\text { Number }\end{array}$ & Complete & $\begin{array}{l}\text { Reduction } \\
\text { Stage }\end{array}$ & $\begin{array}{l}\text { Break } \\
\text { Cause }\end{array}$ & $\begin{array}{c}\text { Maximum } \\
\text { Length }\end{array}$ & $\begin{array}{l}\text { Maximum } \\
\text { Width }\end{array}$ & $\begin{array}{l}\text { Maximum } \\
\text { Thickness }\end{array}$ & $\begin{array}{l}\text { Blank } \\
\text { Type }\end{array}$ & Comments \\
\hline & surface & 33 & Complete & middle & none & 117 & 45 & 21 & indel & point blank \\
\hline & surface & 34 & Complete & early & none & 86 & 36 & 27 & pebble & \\
\hline & surface & 35 & Complete & early-mid & none & 90 & 63 & 28 & flake & \\
\hline & surface & 18 & proximal & Early & manuf & 101 & 45 & 21 & indet & \\
\hline & surface & 20 & Complete & early & none & 70 & 53 & 26 & pebble & with overshot flake scar \\
\hline & surface & 25 & edige & middle & manuf & 40 & 38 & 15 & indet & \\
\hline & surface & 39 & Complete & early & none & 74 & 62 & 33 & pebble & \\
\hline & surface & 19 & edge & early & manuf & 34 & & 16 & indet & \\
\hline & surface & 58 & Complete & early & none & 110 & 79 & 33 & pebble & \\
\hline & suriace & 64 & proximal & eariy & manuf & 69 & 53 & 27 & pebble & \\
\hline & surface & 65 & distal & early & manuf & 63 & 54 & 17 & flake & \\
\hline & surface & 76 & edge. & early & manuf & 53 & 44 & 21 & indet & \\
\hline & surface & 80 & Complete & early & none & 114 & 51 & 29 & indet & \\
\hline & surface & $B 2$ & medial & middle & manuf & 59 & 51 & 19 & indet & \\
\hline & surface & 83 & proximal & early & manuf & 68 & 65 & 16 & tlake & \\
\hline & surface & 84 & proximal & eariy & manuf & 47 & 39 & 16 & flake & \\
\hline & surface & 86 & proximal & early & manuf & 50 & 52 & 14 & flake & \\
\hline & surtace & 87 & proximal & medial & manuf & 43 & 75 & 13 & indet & \\
\hline & surface & 95 & proximal & early & manuf & 78 & 69 & 19 & indet & with overshot flake scar \\
\hline & surface & 102 & Complete & early & none & 110 & 55 & 19 & indet & \\
\hline & surface & 111 & proximal & early & manuf & 53 & 71 & 20 & indet & with basal thinning \\
\hline & surface & 115 & proximal & early & manuf & 54 & 63 & 16 & flake & \\
\hline & surface & 118 & wedge & early & manuf & 25 & 57 & 12 & flake & \\
\hline & surface & 136 & Complete & early & none & 69 & 68 & 34 & pebble & cortex backed pebble \\
\hline & surface & 138 & Complete & early-mid & none & 142 & 61 & 29 & indet & \\
\hline & surface & 167 & edge & middle & indet & 44 & 27 & 14 & indet & \\
\hline & surface & 176 & medial & early & manuf & 52 & 54 & 16 & flake & \\
\hline & surface & 179 & proximal & middle & manuf & 37 & 38 & 10 & indet & \\
\hline & suriace & 182 & proximal & early & manuff & 58 & 57 & 18 & indet & \\
\hline & surface & ui 20 & Complete & middle & none & 74 & 36 & 14 & flake & \\
\hline & surface & Ui 10 & Complete & early & none & 100 & 69 & 30 & indet & \\
\hline & surface & 1 ii 8 & proximal & early & manuf & 60 & 50 & 18 & flake & \\
\hline & surface & पi 20 & proximal & medial & manuf & 44 & 41 & 11 & indet & \\
\hline & surface & ui 4 & Complete & early & none & 67 & 54 & 23 & indet & \\
\hline & surface & 183 & Complete & early & none & 97 & 62 & 33 & indet & \\
\hline & surface & 184 & Complete & early & none & 71 & 59 & 33 & indet & \\
\hline & surface & 185 & proximal & early & indet & 76 & 56 & 30 & pebble & \\
\hline & surface & 205 & distal & middle & manuf & 51 & 58 & 13 & indet & \\
\hline & Surface & 216 & distal & middle & manuf & 59 & 41 & 17 & indet & \\
\hline & surface & 204 & proximal & early & manuf & 46 & 43 & 14 & flake & \\
\hline & surface & 306 & Complete & middle & none & 87 & 53 & 27 & indet & not mapped \\
\hline & Surface & 5 & distal & early-mid & manut & 52 & 35 & 19 & indet & \\
\hline & surface & 252 & Complete & early & none & 113 & 72 & 37 & pebble & with overshot flake scar. \\
\hline & surface & 207 & Complete & middle & none & 74 & 34 & 17 & indet & \\
\hline & surface & 236 & proximal & middle & indet & 40 & 50 & 11 & indet & break face reworked \\
\hline & surface & 237 & proximal & early & indet & 85 & 46 & 21 & indet & break face reworked \\
\hline & surface & 307 & Complete & early & none & 117 & 86 & 38 & pebble & not mapped \\
\hline & surface & 308 & Complete & early & none & 136 & 114 & 45 & pebble & not mapped \\
\hline & surface & 312 & medial & mid-late & manuf & 30 & 62 & 13 & indet & not mapped \\
\hline & surface & 281 & proximal & early & manuf & 58 & 57 & 18 & flake & \\
\hline & surface & Ui 10 & Complete & early & none & 102 & 68 & 31 & indet & \\
\hline & surface & 녀 21 & proximal & early-mid & manuf & 43 & 27 & 7 & flake & has slight. Paleo look \\
\hline & surface & 124 & Complete & early & none & 106 & 80 & 35 & flake & heavily patinated \\
\hline ST 16 & 5 & & medial & middle & manuf & 38 & 43 & 12 & indet & blue patina on both faces \\
\hline ST 17 & 1 & & Complete & early & none & 107 & 56 & 21 & flake & failure to thin a hump \\
\hline ST 15 & surface & & distal & early & manuf & 54 & 49 & 18 & indet & \\
\hline Unit 2 & 3 & & longitudinal & early & manuf & 52 & 35 & 16 & indet & blue patina on both faces \\
\hline Unit 2 & surface & & distal & middle & manuf & 61 & 50 & 12 & indet & \\
\hline Unit 1 & 2 & & medial & middle & manuf & 45 & 28 & 12 & indet & \\
\hline Unit 1 & 1 & & biface edge & middle & indet & & & 7 & indet & \\
\hline ST 17 & 2 & & distal & early & indet & 33 & 20 & 15 & indet & blue patina on both faces \\
\hline
\end{tabular}


Appendix 1.7.

Miscellaneous unifaces from 41BX1412

\begin{tabular}{|c|c|c|c|c|c|c|c|c|c|}
\hline Unit & Level & $\begin{array}{c}\text { Npecimen } \\
\text { Number }\end{array}$ & Blank Type & Uniface Type & Completeness & Length & Width & Thickness & \\
\hline ST 20 & 2 & & secondary flk & indeterminate fraq. & proximal & & & 11.5 & not patinated, secondary flk blank proximal fraa. \\
\hline EU 2 & 6 & & primary flk & indet. distal frag. & distal & & 37.5 & 21 & two adiacent edaes flaked from alternate faces of flake; no wear \\
\hline EU 3 & 4 & & secondary flk & indet. edge frag. & edge frag. & & & 6 & not patinated. \\
\hline & surf. & 40 & secondary flk & minimally ret & complete & 66 & 49 & 16 & not patinated; most retouch adjacent to two corners; no wear \\
\hline
\end{tabular}


Appendix 1.8.

\section{Cores from 41BX1412}

\begin{tabular}{|c|c|c|c|c|c|c|c|c|c|}
\hline Unit & Level & $\begin{array}{c}\text { Specimen } \\
\text { Number }\end{array}$ & Complete & $\begin{array}{c}\text { No. of Flk. } \\
\text { Scars }\end{array}$ & Core Type & $\begin{array}{c}\text { Maximum } \\
\text { Length }\end{array}$ & $\begin{array}{c}\text { Maximum } \\
\text { Width }\end{array}$ & $\begin{array}{l}\text { Maximum } \\
\text { Thickness }\end{array}$ & Comments \\
\hline & surface & 36 & Complete & 12 & multi-direct & 87 & 79 & 39 & \\
\hline & surface & 37 & Complete & 9 & unidirect & 82 & 77 & 37 & 85 deg \\
\hline & surface & 8 & Complete & 9 & multi-direct & 81 & 67 & 63 & \\
\hline & surface & 22 & Complete & 3 & multi-direct & 61 & 50 & 34 & \\
\hline & surface & 41 & Complete & 8 & unidirect & 70 & 68 & 53 & \\
\hline & surface & 43 & Complete & 1 & unidirect & 84 & 72 & 34 & 83 deg \\
\hline & surface & 62 & Complete & 6 & unidirect & 112 & 104 & 62 & 85 deg \\
\hline & surface & 75 & Complete & 2 & multi-direct & 101 & 71 & 52 & tested core \\
\hline & surface & 90 & Complete & 11 & unidirect & 75 & 60 & 42 & \\
\hline & surface & 100 & Complete & 8 & unidirect & 110 & 82 & 70 & single platf., $60-77$ deg. \\
\hline & surface & 110 & Complete & 6 & unidirect & 73 & 58 & 38 & 68 dea \\
\hline & surface & 114 & Complete & 23 & unidirect & 82 & 48 & 45 & \\
\hline & surface & 127 & Complete & 4 & bidirect & 120 & 64 & 55 & \\
\hline & surface & 137 & frag & 11 & multi-direct & 72 & 72 & 48 & \\
\hline & surface & 143 & Complete & 7 & bidirect & 59 & 54 & 47 & $86 \mathrm{deg}$ \\
\hline & surface & 156 & Complete & 5 & multi-direct & 66 & 50 & 49 & \\
\hline & surface & 170 & Complete & 12 & multi-direct & 72 & 55 & 38 & \\
\hline & surface & 177 & Complete & 8 & unidirect & 78 & 68 & 35 & \\
\hline & surface & ui 6 & Complete & 4 & unidirect & 79 & 69 & 43 & $85 \mathrm{deq}$ \\
\hline & surface & ui 5 & Complete & 1 & unidirect & 141 & 123 & 50 & tested core \\
\hline & surface & 188 & Complete & 14 & unidirect & 74 & 51 & 30 & 86 deq \\
\hline & surface & 190 & Complete & 9 & unidirect & 85 & 60 & 43 & $85 \mathrm{deg}$ \\
\hline & surface & 192 & Complete & 4 & unidirect & 87 & 61 & 32 & $54 \mathrm{deq}$ \\
\hline & surface & ui 13 & Complete & 9 & multi-direct & 77 & 58 & 41 & \\
\hline & surface & 191 & Complete & 5 & bidirect & 112 & 87 & 27 & \\
\hline & surface & 231 & Complete & 6 & bidirect & 98 & 68 & 61 & \\
\hline & surface & 239 & Complete & 3 & unidirect & 79 & 69 & 46 & 78 dea \\
\hline & surface & 309 & Complete & 5 & unidirect & 86 & 49 & 44 & 82 deg. not mapped \\
\hline & surface & 213 & Complete & 5 & unidirect & 97 & 64 & 45 & $58 \mathrm{deg}$ \\
\hline & surface & 210 & Complete & 2 & unidirect & 82 & 61 & 44 & tested core \\
\hline & surface & 212 & Complete & 7 & bidirect & 79 & 74 & 64 & \\
\hline & surface & 220 & Complete & 8 & multi-direct & 91 & 76 & 51 & \\
\hline & surface & 223 & Complete & 6 & bidirect & 137 & 106 & 86 & \\
\hline & surface & 311 & Complete & 5 & unidirect & 89 & 72 & 22 & 68 deg \\
\hline & surface & 211 & Complete & 2 & multi-direct & 73 & 64 & 51 & \\
\hline & surface & 239 & Complete & 3 & unidirect & B1 & 62 & 43 & \\
\hline & surface & 233 & Complete & 3 & unidirect & 73 & 67 & 39 & \\
\hline & surface & 230 & Complete & 7 & unidirect & 130 & 111 & 63 & may be cobble tool \\
\hline ST 10 & 2 & & Complete & 3 & unidirect & 35 & 31 & 22 & \\
\hline
\end{tabular}




